\title{
Entrepreneurs' Exit Strategy Intentions and Their Final Exit Paths
}

\author{
Sascha Hohen $\mathbb{D} \cdot$ Lars Schweizer $\mathbb{D}$
}

Accepted: 1 November 2021 / Published online: 23 November 2021

(C) The Author(s) 2021

\begin{abstract}
This paper explores entrepreneurs' initially intended exit strategies and compares them to their final exit paths using an inductive approach that builds on the grounded theory methodology. Our data shows that initially intended and final exit strategies differ among entrepreneurs. Two groups of entrepreneurs emerged from our data. The first group comprises entrepreneurs who financed their firms through equity investors. The second group is made up of entrepreneurs who financed their businesses solely with their own equities. Our data shows that the first group originally intended a financial harvest exit strategy and settled with this harvest exit strategy. The second group initially intended a stewardship exit strategy but did not succeed. We used the theory of planned behavior and the behavioral agency model to analyze our data. By examining our results from these two theoretical perspectives, our study explains how entrepreneurs' exit intentions lead to their actual exit strategies.
\end{abstract}

Keywords Entrepreneurial Exit Intentions · Financial Harvest Exit Strategy • Stewardship Exit Strategy · Theory of Planned Behavior · Behavioral Agency Model

This paper was originally submitted and independently peer-reviewed at "Business Research (BURE)", one of SBUR's predecessor journals. It has been accepted by the same Editor-in-Chief for publication in the successor journal SBUR.

Availability of data and material: Data and material are available from the authors upon request.

Code availability: Not applicable.

Sascha Hohen $(\bowtie) \cdot$ Lars Schweizer

Chair of Strategic Management, Goethe University Frankfurt,

Theodor-W.-Adorno-Platz 4, 60323 Frankfurt am Main, Germany

E-Mail: S.Hohen@stud.uni-frankfurt.de

Lars Schweizer

E-Mail: L.Schweizer@em.uni-frankfurt.de 


\section{JEL Codes $\mathrm{L} 26 \cdot \mathrm{G} 34 \cdot \mathrm{L} 14$}

"I used to assert myself on the market. Unfortunately, not in the family! No child wanted to take over the company. [...] At some point, at fifty, fifty-five, you start thinking about who you are doing all that stuff for! And after all children have turned it down-sell it!" (Interviewee A06)

\section{Introduction}

Entrepreneurial exits are procedures by which the owners of privately held companies remove themselves from their firms' ownership and decision-making structure (DeTienne 2010). Owner exits are significant events in the lifecycle of firms, especially in small entrepreneurial ventures (Aldrich 2015; DeTienne and Wennberg 2016), but there is little understanding of these significant processes (DeTienne et al. 2015). DeTienne and Wennberg (2016, p. 155) argue that there is "much to be done in studies of entrepreneurial exit" before this area can provide "an understanding concomitant with what we know about new start-ups or new venture growth."

"Recent years have seen an increasing focus on entrepreneurial exit in a number of specialized workshops and conferences, new research projects, and special issues in international journals" (Wennberg 2021, p. 274). In these works, entrepreneurship scholars study the influence of funding resources on exit strategies (Albert and DeTienne 2016), the effects of firm relocation on entrepreneurial exits (Jenkins et al. 2016), why founders of well-performing start-up firms are forced to exit their firms by venture capitalists just to be replaced by experienced managers (Ewens and Marx 2018), the relation between mental health and entrepreneurial exits (Hessels et al. 2018), entrepreneurs' retirement approaches and their implications for entrepreneurs' exit strategies (Morris et al. 2020), and reasons founders exit from high-potential ventures via initial public offerings (Souitaris et al. 2020).

Despite these advances in entrepreneurial exit literature, some crucial areas remain poorly understood. In particular, basic connections from entrepreneurs' exit intentions to the actual exit outcomes are not measured nor understood (DeTienne and Wennberg 2016; Wennberg and DeTienne 2014). Wennberg and DeTienne (2014, p. 7) argue that exit intention research "is still in its infancy, and there is so much more to understanding the phenomenon." They point out concrete avenues for future research, stating that "additional research is needed to understand how intentions lead to specific exit strategies" and "how, or if, intentions change over time" (Wennberg and DeTienne 2014, p. 7). Likewise, Sardeshmukh et al. (2021, p. 544) state that "entrepreneurial exit and exit intentions are emerging areas of research, yet psychological antecedents of such intentions are understudied." Additionally, Chirico et al. (2020) state that very little is known about differences in exit decisions by firm owners to date. Accordingly, further research on exit intentions in entrepreneurial exit literature is needed. This paper will address this research gap by answering the following research question:

Do entrepreneurs' exit strategy intentions change over time, and if so, why? 
Scholars have noted that individuals become entrepreneurs and operate their own firms for a wide variety of reasons (Wennberg and DeTienne 2014). Parker et al. (2010) assume that, in the same vein, there are several reasons why an entrepreneur may want to quit entrepreneurship, considering entrepreneurial exits as a multidimensional phenomenon. To reduce this heterogeneity, the current study focuses only on exit via acquisitions as harvest exit strategies (Wennberg and DeTienne 2014). Mergers and acquisitions (M\&A) are important instruments in a firm's strategy repertoire. M\&A activities initiate profound organizational change that can alter whole industry architectures (Graebner et al. 2017; Welch et al. 2020). Since the total yearly value of worldwide M\&A activities continually grows (Welch et al. 2020), the understanding of M\&A activities among entrepreneurs is especially important for theory and practice. Therefore, our study focuses on entrepreneurs who left their firms through acquisitions by other party.

Our study utilizes a grounded theory approach (Corbin and Strauss 2015) that includes 28 interviews as a primary data source. In doing so, this paper contributes to the entrepreneurial exit intention literature by providing deep insights into how entrepreneurs' exit intentions lead to their actual exit strategies. Furthermore, explanations for entrepreneurial exit intentions are presented by applying the behavioral agency model (Wiseman and Gómez-Mejía 1998) and the theory of planned behavior (Ajzen 1991, 2011; Ajzen and Fishbein 1980).

This paper is structured as follows. Sect. 2 presents the theoretical background of the study and provides a literature overview. We illustrate the design of our study, including how data were collected and analyzed, in Sect. 3. The results and propositions of the study are presented in Sect. 4 . We critically discuss our findings in Sect. 5. The theoretical contributions and practical implications are explained in Sects. 6 and 7. Limitations of the study and avenues for future research can be found in Sect. 8. A short conclusion is presented in the final section.

\section{Theoretical Background and Literature Overview}

We conducted a literature search to find studies that are related to entrepreneurial exit intention research. ${ }^{1}$ Entrepreneurial exit literature typically focuses on owners of privately held firms (e.g., DeTienne 2010; DeTienne and Cardon 2012; Gimeno et al. 1997; Van Teeffelen and Uhlaner 2013; Wennberg et al. 2010). In the subsections that follow we introduce a classification of entrepreneurial exit strategies (DeTienne and Cardon 2012; Wennberg and DeTienne 2014) and present the socioemotional wealth model developed by Gómez-Mejía et al. (2007) as an extension of the behavioral agency model (Wiseman and Gómez-Mejía 1998). The model allows us to identify assets that entrepreneurs intend to preserve, with their particular exit strategy. Moreover, we introduce the theory of planned behavior (Ajzen 1991, 2011; Ajzen and Fishbein 1980) which, together with the socioemotional wealth model,

\footnotetext{
1 The authors used the EBSCOhost database for literature search. All keyword lists and database search results are available from the authors upon request.
} 
helps us to understand how entrepreneurs' exit intentions lead to their actual exit strategies.

\subsection{Entrepreneurial Exit Strategies}

Early research tended to equate entrepreneurial exit with failure, assuming that the exit is a direct consequence of the firm owner's incapability to operate a lucrative business (e.g., Bates 2005; Headd 2003; Laitinen 1992). Hence, survival and continuation were depicted as successful outcomes (Brüderl et al. 1992; Pennings et al. 1998). Recent studies have taken a more fine-grained approach, showing that entrepreneurs leave their businesses for various reasons (Hsu et al. 2016). Moreover, scholars have found out that firm performance alone is insufficient when explaining the choice between exit and persistence. Wennberg et al. (2010) found that over half of all entrepreneurial exits occurred in firms that showed no signs of financial distress. Therefore, a business exit is not necessarily due to low firm performance or better alternatives. Firm exits can also be linked to entrepreneurs' personal motives (Justo et al. 2015). Entrepreneurial exit literature has identified different exit options, known as exit strategies or exit paths. These exit options have been categorized into three main types: financial harvest, stewardship, and voluntary cessation (DeTienne and Cardon 2012; Wennberg and DeTienne 2014).

Financial harvest exit strategies, such as an initial public offering (IPO) and acquisition by another company, are primarily linked to financial aspects (Cumming 2008; Poulsen and Stegemoller 2008). While these exit strategies are rather complex, they offer high financial returns (Babich and Sobel 2004; DeTienne and Cardon 2012). An initial public offering is often used to create funds for growth, and founders frequently remain in their companies for extended time (Daily et al. 2003). On the other hand, firm acquisition often results in the prompt replacement of the former owner (DeTienne and Cardon 2012). Acquisition of a target firm enables the acquirer to gain immediate access to valuable assets, including technologies, qualified employees, and intellectual property (Ahuja and Katila 2001; Graebner et al. 2017; Haleblian et al. 2009; Ranft and Lord 2002; Seth et al. 2002; Welch et al. 2020). Furthermore, M\&A activities ensure the acquirer gain rapid market access by taking over the target firm's marketing channels, supply networks, and customers (Capron et al. 2001). Mergers and acquisitions can help advance economies of scale and economies of scope, or eliminate a competitor (Graebner et al. 2017). International M\&A activities allow the acquirer to achieve geographical market diversification that can reduce sale fluctuation (Denis et al. 2002). Most M\&A literature explores the antecedents and outcomes of M\&A activities from the acquirer's perspective, and the target firms receive less research attention (Dalziel 2008; Graebner and Eisenhardt 2004; Graebner et al. 2010; Zeng et al. 2013).

Stewardship exit strategies focus on social and pro-organizational behavior that allows a founder to influence a company's future even after the founder's exit (DeTienne et al. 2015; Hernandez 2012; Zellweger and Astrachan 2008). Stewardship exit strategies are succession or buyouts, such as family succession or management buyouts. Family succession involves transferring ownership of a company to a family member, typically the entrepreneur's children (DeTienne and Cardon 2012). 
Entrepreneurship scholars propose that transferring a company to a family member depends greatly on nonfinancial issues such as family relationships and long-term business orientation (Cater and Justis 2009; Zellweger et al. 2012).

Voluntary cessation exit strategies allow the founder to dissolve a venture when the primary activity ends or when the company achieves the purpose it was established for. Voluntary cessation exit strategies imply that the entrepreneurs' companies will end operations permanently. Voluntary liquidation happens after firm closure and implies that all assets and property of the company are sold. It should be noted that bankruptcy is not a voluntary cessation exit strategy since the entrepreneur has no choice (DeTienne et al. 2015; Harhoff et al. 1998; Schary 1991).

\subsection{Behavioral Agency Model}

The behavioral agency model was first introduced by Wiseman and Gómez-Mejía (1998). The model combines elements of the agency theory (Jensen and Meckling 1976; McGuire 1988; Rees 1985; Shavell 1979), the prospect theory (Kahneman and Tversky 1979), and the behavioral theory of the firm (Cyert and March 1992; March and Shapira 1992). The behavioral agency model was created to analyze decisions under risk within an agent situation. It challenges the agency theory's concept of consistent risk aversion among agents. Built on the conception of risk-bearing and loss aversion (Cyert and March 1992; March and Shapira 1992), the behavioral agency model suggests that agents' risk preferences are not static. Instead, risk preferences depend on the situational context (Wiseman and Gómez-Mejía 1998). The model builds on the hypothesis that agents are averse to loss and accept risks to avoid loss of wealth (Wiseman and Gómez-Mejía 1998).

Subsequently, Gómez-Mejía et al. (2007) developed a socioemotional wealth model based on the behavioral agency model. The socioemotional wealth model can be understood as an extension of the behavioral agency model that explains decisions in family firms. It has become a key concept in family firm research (Schulze and Kellermanns 2015). The model has been used in numerous entrepreneurship-related studies (e.g., Chirico et al. 2020; Gómez-Mejía et al. 2019; Kotlar et al. 2018; Leitterstorf and Rau 2014; McLarty and Holt 2019; Souder et al. 2017). It focuses on family firm principals' decisions when at risk of losing wealth. Gómez-Mejía et al. (2007) state that the wealth of family firm principals includes financial wealth and socioemotional wealth. Socioemotional wealth includes the principal's social ties to stakeholders, and the principal's emotional attachment to and identification with the firm. Moreover, socioemotional wealth involves family control over the company and transgenerational succession (Berrone et al. 2012; Chrisman and Patel 2012; Gómez-Mejía et al. 2007, 2011). Zellweger and Dehlen (2012, p. 282) define socioemotional wealth as "the absolute difference between an owner's subjective value assessment and the objective market value for the ownership stake of a firm." The principal's socioemotional wealth originates from sources such as a positive public image of the company, especially when the company bears the owner's name, or the pride that family members work in critical positions in the company (Berrone et al. 2012; Chrisman and Patel 2012; Gómez-Mejía et al. 2011). 
When comparing business decisions between family firms and non-family firms, Gómez-Mejía et al. (2007) note that a key criterion that influences business decisions of family firms is the preservation of socioemotional wealth. In contrast, the authors state that for non-family firms, financial wealth "seem[s] to be most important when it comes to assessing the value of a business decision, as they are less driven by the need to protect their socioemotional endowment" (Gómez-Mejía et al. 2007 , p. 131). Financial wealth and socioemotional wealth preservation can explain business outcomes in family firms. Socioemotional wealth represents a valued asset for family firm owners that they intend to preserve (Gómez-Mejía et al. 2011; Hoskisson et al. 2017). In other words, family firm principals are averse to loss in terms of socioemotional wealth, and this is mirrored in their business decisions.

\subsection{Theory of Planned Behavior}

The theory of planned behavior (Ajzen 1991, 2011; Ajzen and Fishbein 1980) is prominent in social psychology. It builds on the theory of reasoned action (Fishbein and Ajzen 1975) and proposes that the likelihood of an individual's specific behavior depends on the individual's intention to engage in this particular behavior (Ajzen 1991, 2011; Ajzen and Fishbein 1980).

Ajzen $(1991,2011)$ states that three factors determine an individual's planned behavior. First, the individual's attitude towards a specific behavior. This factor stands for the desirability of the outcome for the individual. The theory declares that an individual's intention to perform a behavior increases as the individual's attitudes towards the specific behavior become more favorable (Ajzen 1991, 2011; Ajzen and Fishbein 1980). Second, the evaluation of the specific behavior according to the subjective social norms of an important reference group. This factor stands for the perceived social standard that can imply performing or not performing the particular behavior. The theory of planned behavior indicates that an individual's intention to perform a particular behavior increases as social norms become more favorable (Ajzen 1991, 2011; Ajzen and Fishbein 1980). Third, the perceived behavioral control, which stands for an individual's notion of the ease or difficulty of performing a specific behavior. This factor reflects the feasibility of a specific behavior, such as the dependency on certain persons to accomplish the desired outcome. An individual's intention to perform a specific behavior increases with the perceived behavioral control variable. When these three factors are fulfilled, an intention likely provokes an actual behavior (Ajzen 1991, 2011; Ajzen and Fishbein 1980). Serval studies support a connection between intentions and behavior (e.g., Arnold et al. 2006; Kautonen et al. 2015; Krueger and Carsrud 1993; Ozkan and Kanat 2011; Sheppard et al. 1988).

The theory of planned behavior is primarily used in the field of social psychology. Entrepreneurship scholars also use the theory of planned behavior as a framework in their studies (e.g., Carsrud and Brännback 2011; Esfandiar et al. 2019; Fayolle and Liñán 2014; Krueger 2009; Soleimanof et al. 2016; Lee et al. 2011; Liñán and Chen, 2009). The theory has been used to explore the influence of entrepreneurship education programs on students' intention to start a business (Sánchez 2013) and to understand proactive environmental strategies in family firms (Sharma and 
Sharma 2011). Moreover, it has been employed to identify factors that drive young researchers to set up ventures based on their research results (Feola et al. 2019). Scholars utilize the theory of planned behavior to investigate the role of resilience and its effect on entrepreneurial intentions (González-López et al. 2019), to understand the behavior of family firm leaders (Chua et al. 2003), to link founders' retirement intentions to firm exits (Soleimanof et al. 2016), and to explore the influence of prior family business exposure on an individual (Carr and Sequeira 2007). These studies suggest that the theory of planned behavior is well fitted for research in entrepreneurship, especially to understand the link between entrepreneurs' exit intentions and their actual exit paths.

\section{Research Design}

The mentioned research gap in entrepreneurial exit intention literature suggests an explorative research design. Theory building using a qualitative approach seems much more appropriate than theory testing. Miles et al. (2019) recommend that researchers use inductive approaches when there is a need for deep understanding, contextualization, and causal inference. Likewise, Eisenhardt (1989) states that inductive studies are most suitable for generating an initial understanding of a process.

The grounded theory methodology is a well-established qualitative approach in the social sciences (Glaser and Strauss 1967; Corbin and Strauss 2015). Using this methodology, the researcher analyzes data by intentionally excluding assumptions. Categories are then developed from the empirical data. These categories are constantly reviewed, structured, modified, and expanded. As a result, relationships are recognized and then compacted into core categories. Two prominent variants of the grounded theory approach exist. One is a more constructivist variant (Charmaz 2014), while the other is a more objectivist approach (Corbin and Strauss 2015) that follows a positivist philosophy. When using the objectivist grounded theory approach, data is discovered by neutral but informed observers in an external world. Objectivists look from the outside into the empirical world as visitors, but they do not enter the observed world. The objectivist approach follows a prescriptive analytic process that is usually more formalized than the constructivist approach. However, despite this formalized process, the researcher does not study facts since empirical data typically includes subjective opinions and stories of interviewees.

On the other hand, the constructivist grounded theory approach emphasizes more on situations and conditions that affect the data collection and analysis process. Moreover, the representation of data is seen as problematic, relativistic, situational, and incomplete (Charmaz 2014; Flick 2018; Patton 2015; Pernecky 2016). Both approaches focus on a better understanding of the phenomenon that is being studied rather than on generalizable results. Choosing either the objectivist or constructivist variant depends mainly on the ontological viewpoint of the researcher. Since both authors of the current paper have a positivist research philosophy, the objectivist approach was chosen, and the procedure outlined in Corbin and Strauss (2015) was followed. The research project uses a cross-sectional design (Goddard and Melville 2004) due to its limited time resources. 


\subsection{Data Collection}

Interviews are a common source of data in the objectivist grounded theory approach (Corbin and Strauss 2015; Strauss and Corbin 1990). Thus, we used in-depth interviews with entrepreneurs who have left their firms by completely selling their shares as a primary data source (see Table 1). The search for interviewees was restricted to Germany. We combined real-time with retrospective cases. Retrospective cases can build up the number of cases efficiently since they provide the researcher with more informants (Leonard-Barton 1990).

We utilized triangulation during the study. In this context, triangulation means that the object of interest is examined from multiple perspectives. That can be a valuable addition to understanding events and can increase the validity and robustness of a study (Flick 2018; Jick 1979; Miles et al. 2019; Pettigrew 1992; Yin 2018). Moreover, triangulation allows for a greater expanse of knowledge (Denzin 1989, 2009). Thus, eight consultants were interviewed in addition to twenty interviewed entrepreneurs. These consultants have been involved in numerous entrepreneurial exits, mainly exits via mergers and acquisitions. The selection criterion for these advisors was that they must have long-lasting M\&A experience with entrepreneurial target firms (see Table 2). Additional sources, such as press releases, company brochures, websites, and informal telephone follow-ups, were also used. These data sources and informal conversations (e.g., at meetings, entrepreneurial fairs, or telephone followups) were mainly used for reflection or summary memos.

All interviews were tape-recorded. Since we wanted to get as much unfiltered and reliable information as possible, we guaranteed confidential treatment of the tape recordings and anonymity to the interviewees. It was not possible that the interviewees' answers influenced each other's since all interviews were conducted separately. None of the interviewees and the authors were acquainted prior to the interviews. Different sources were used to find appropriate candidates. First, public sector economic organizations (e.g., Federal Ministry for Economic Affairs and Energy), employers' associations, and M\&A advisors were asked to establish contacts with entrepreneurs. Moreover, we joined a trade fair for start-ups to get in touch with entrepreneurs. Second, we posted about our study and asked for participants in various entrepreneur forums and newsgroups (e.g., Business Angels Network Germany and Xing). Third, business and news websites were searched for current entrepreneurial M\&A activities. Fourth, the snowball sampling technique was used (Denzin and Lincoln 2017) by asking interviewees to reach out to other entrepreneurs who sold their companies. Getting information from public authorities was difficult due to strict German data protection laws. We had to put a lot of effort into building contacts with M\&A consultants and entrepreneurs to find suitable interviewees from their professional circles. Most of our interviewees came from these sources. This exhausting procedure took a significant amount of effort and over nine months to complete.

In sum, we contacted 214 entrepreneurs via e-mail, on the phone, or in-person and published 37 forum posts to find 28 interviewees. All interviewees were interviewed once. The 28 interviews lasted $1480 \mathrm{~min}$ in total, which is approximately $53 \mathrm{~min}$ per interview. All interviews were conducted in German by the authors themselves. 


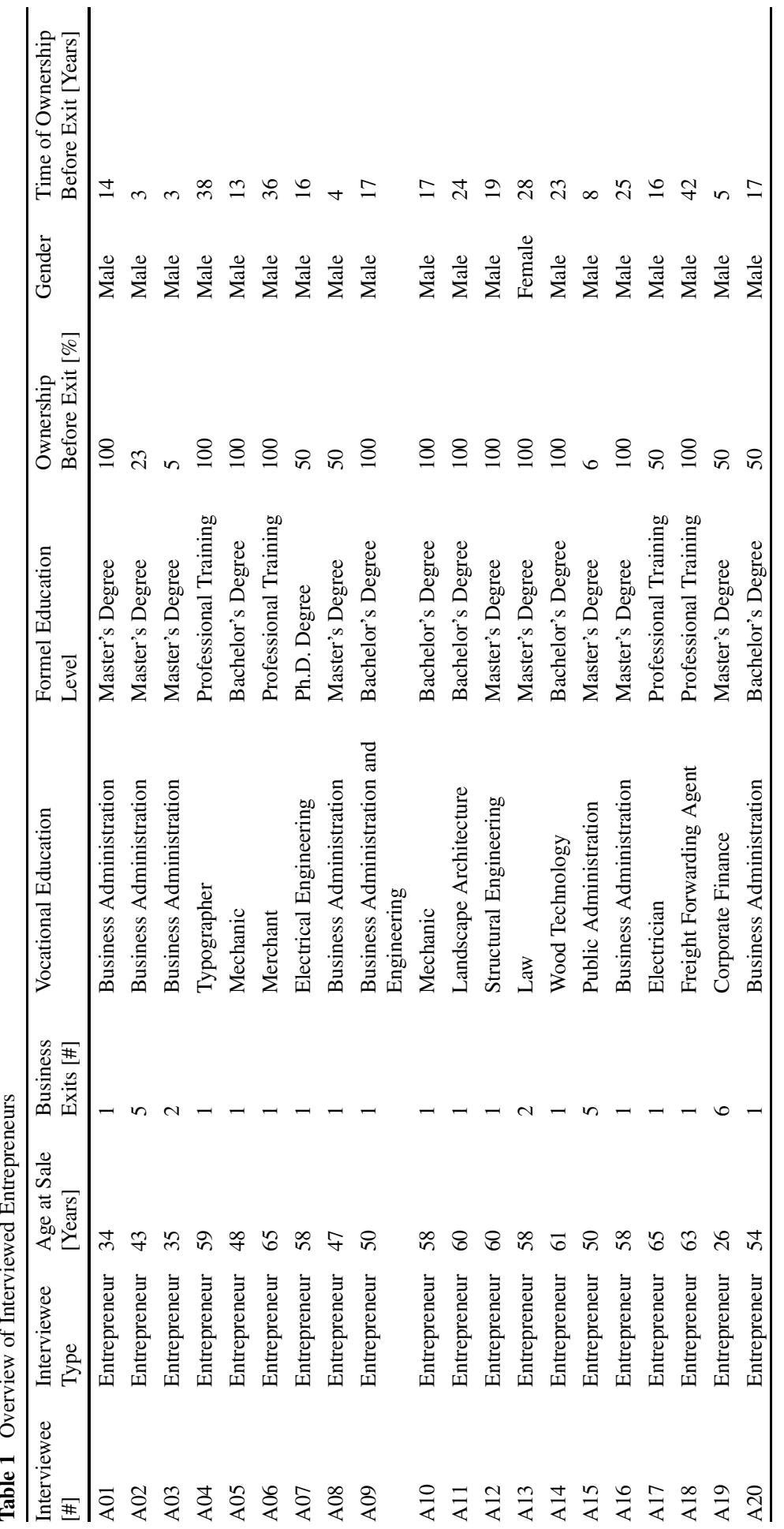




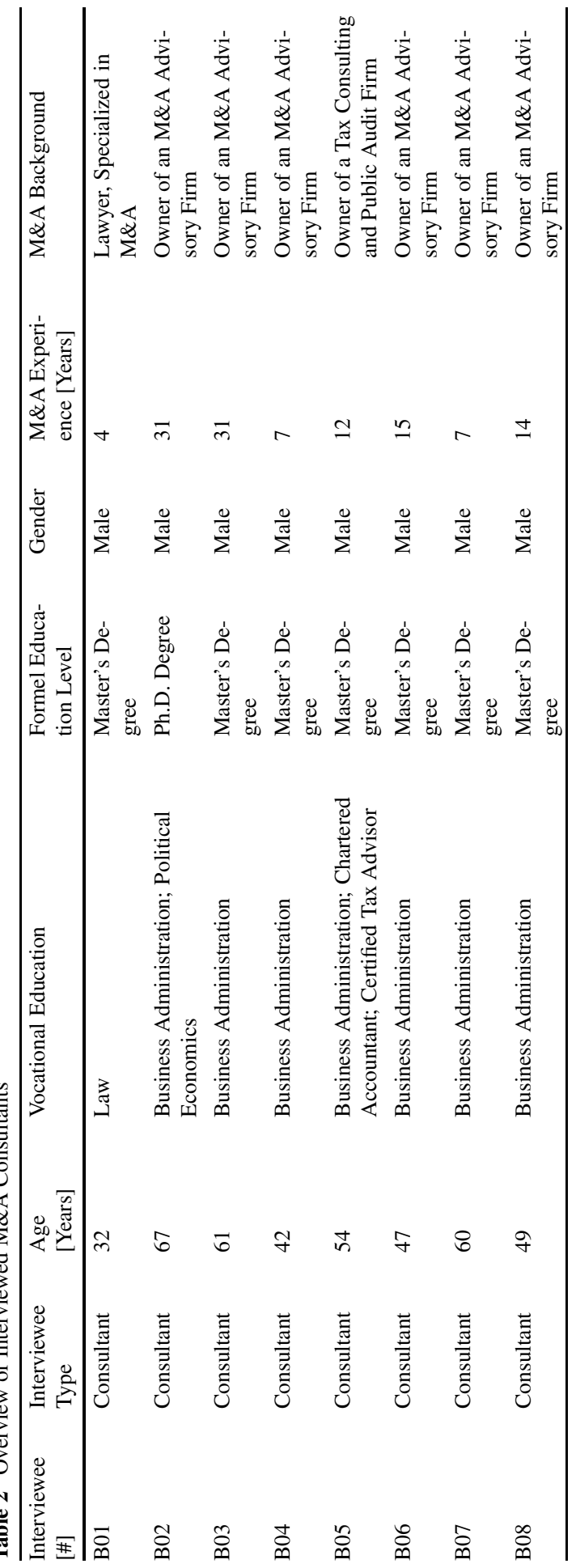


The authors adopted a neutral, interested-restrained conversation style during the interviews. The aim was to have mostly free conversations with the interviewees. The interviewees' responses were translated into English. The content validity of the translated responses had been verified by the authors. The interviews were conducted via Skype, in-person, or on the phone. The transcriptions of the interviews filled a total of 877 pages, complemented by 44 pages of field notes and 113 pages of memos.

The interviewees' companies were all privately held and could be categorized as small and medium-sized enterprises (SME). Five of the companies had received venture capital or funding by angel investors. All interviewees made considerable sales, had numerous employees and managed to survive in the market for several years. The interviewees founded their businesses out of performance orientation and to reach financial wealth. Therefore, we considered all interviewees of our sample as growth entrepreneurs (Wennberg and DeTienne 2014). When theoretical saturation occurred, suggesting that more interviews would add no significant value to the study, we stopped data collection.

\subsection{Data Analysis}

The procedure outlined by Corbin and Strauss (2015) was followed to code, structure, and order the sample data. The transcribed text of the interviews was initially coded line by line. This time-consuming process ensures that the study is genuinely grounded and that higher-level categories emerge from the data rather than being imposed upon it. In the later stages of the data analysis, larger chunks of text were coded. The sentences and paragraphs in the transcribed text were then labeled. We made connections between the initial codes to develop themes and reach a more conceptual level. We moved back and forth between data collection and analysis (see Fig. 1). Emerging assumptions were checked against reality. This means that we looked for incidents that challenge or confirm the developing assumptions (theoretical sampling). Finally, the overarching theoretical dimensions (core categories) were identified, and a theory was developed out of these dimensions (Corbin and Strauss 2015). This process was repeated until category development was dense, detailed, and differentiated.

We interacted with rich data during the research process. By examining these data, ideas came up about how concepts might be related to each other. These thoughts were written down in the reflection, summary, and theoretical memos during the research process. Thus, we were able to document the process of the theoretical development of our study. The qualitative data management software QSR NVivo 12 was used to manage and analyze the empirical data. All interviews were transcribed verbatim, following the transcription rules outlined in Kuckartz (2018). These transcription rules are specially made for computer-based qualitative empirical research and support the statistical analyses of the lines and the lexical search function of the software program. 


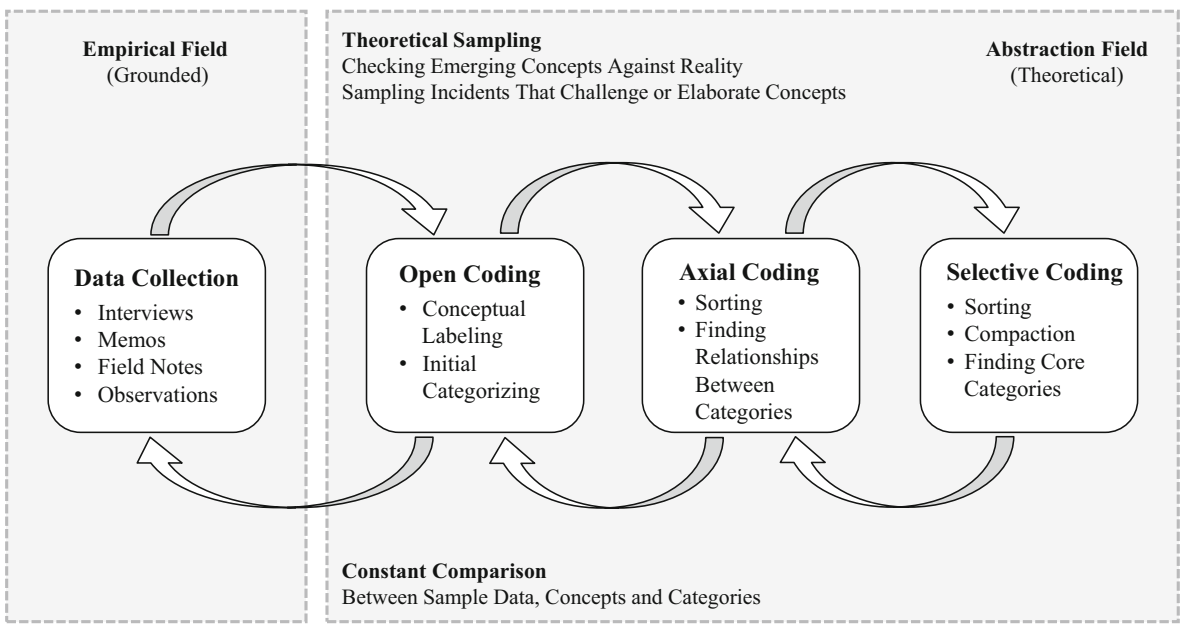

Fig. 1 Grounded Theory Data Analysis Procedure (Corbin and Strauss 2015)

\section{Results}

We found substantial differences in the intended exit strategies among the interviewed entrepreneurs. We traced these different exit intentions by comparing entrepreneurs' attributes on the personal and firm level. Gradually, two groups emerged through the research process. These groups had significantly different exit intentions but left their firms through the same exit strategy (acquisition by a third party). Several interviewed consultants noticed differences between exiting entrepreneurs as well. Interviewee B02 is a 67-year-old M\&A consultant with over 31 years' M\&A experience. He described the differences between the exiting entrepreneurs as follows:

These are just two different worlds! [...] These are too big differences! Normally, I do not fund a startup to build a family business. I rather develop an idea and see it as an entrepreneurial activity with which I earn money. And then there is always an exit or IPO somehow included in the commitment. [...] There is a shareholder agreement, there is a lot of stuff in there, and those young people are already pressured, actually before they have started. They must see that they get a strong growth and then, after year three or four, slowly start to look for an exit. (Interviewee B02)

Our sample data shows that the two groups manifest themselves primarily through the financing structure of their firms, while other factors (e.g., industry and company size) play a secondary role. The first group consists of entrepreneurs who financed their companies through equity investors (i.e., venture capital and angel investors). We call this group investor-backed entrepreneurs. Interviewees A02, A03, A08, A15, and A19 belong to this group. These firm owners were active in internet-related industries (i.e., online travel portal, e-commerce, IT services, software, and online marketing agency). Compared to the other interviewees, these entrepreneurs are, 
on average, younger and more educated, and managed their companies for shorter duration before selling them. Moreover, these entrepreneurs owned fewer shares in their companies than the entrepreneurs in the other group because they were financed by equity investors and partners. Their business ideas were more technology-driven. The second group comprises entrepreneurs who financed their companies with debt capital or owner's equity. We call this group self-funded entrepreneurs. All other interviewees belong to this group. To explain the different exit intentions between the two groups, they are described separately.

\subsection{Self-Funded Entrepreneurs' Exit Strategy Intentions}

Our grounded theory framework illustrates first-order concepts and second-order themes that explain why the interviewees of the self-funded group opted for acquisition as an exit strategy (see Fig. 2).

The interviewees of the self-funded group are owners and managing directors at the same time. Most of the self-funded entrepreneurs are quite old, and they became aware as they aged that they would soon have to consider their exit from their firms. The following conversation with A17, a 70-year-old interviewee, illustrates this.

Interviewer: How did the firm sale come about? What were the reasons for you? [...] Interviewee A17: In the end, it was age! I have now reached seventy and there was therefore the thought of what to do now.

The majority of the self-funded entrepreneurs worked for decades in their companies as managing directors. They became strongly attached to their businesses over the years. A statement by A06, a 65-year-old interviewee who owned a mechanical engineering company for 36 years and employed more than 80 people, illustrates this point. The interviewee described his attachment in the following conversation:

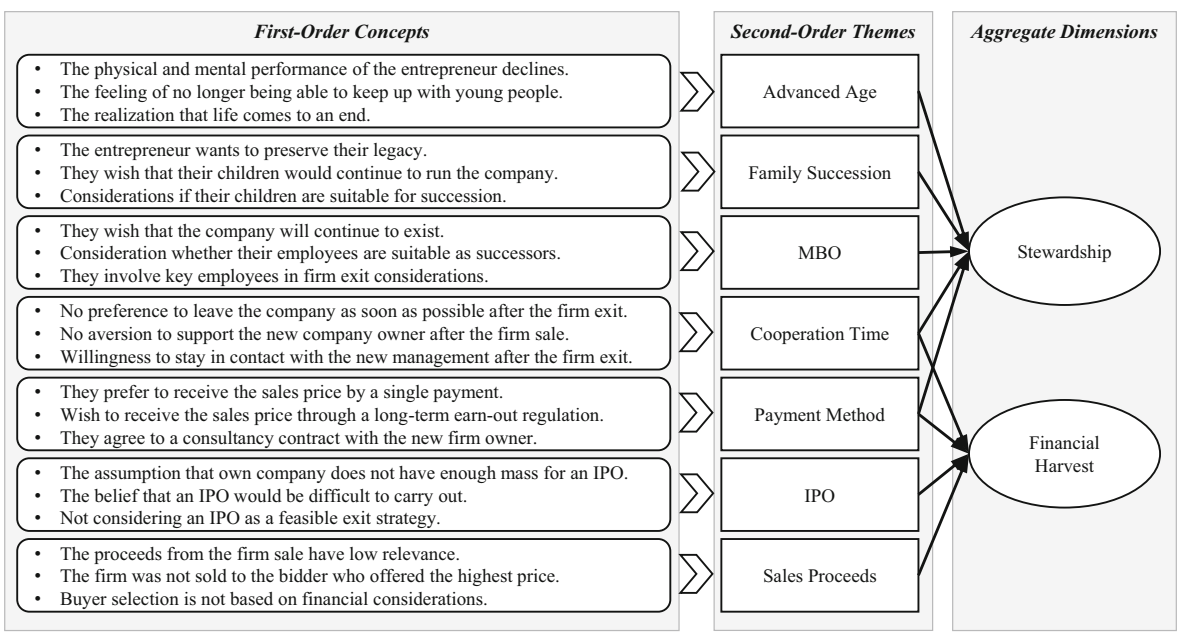

Fig. 2 Exit Strategy Intention of Self-Funded Entrepreneurs 
Interviewee A06: Think of a classic car! You cleaned it for twenty years. Then your wife says, "get rid of that thing!" You have to sell it. Then comes a strange guy [who wants to buy the company]. You say, "no, I will not sell it to him." Interviewer: You wanted to leave it in good hands? Interviewee A06: Yes, exactly! Interviewer: Okay. Interviewee A06: It was my child! I wanted to pass it on. It still bears my name [his former company still bears this family name after the firm sale]. [...] I want to walk through the world with my head held high!

In another example, A01, a 54-year-old interviewee, explained how self-funded entrepreneurs feel when they have to exit their companies. According to him, when entrepreneurs build a company, they do not want it to decay after their exit. Interviewee A01 further stated that entrepreneurs need to arrange succession in advance because they are not only at risk of financial loss but also of emotional loss.

Usually, there is a lot of passion involved. It was the same with me. You can only run a company of this size with passion. If you cannot arrange the succession, then you have a huge problem! Emotionally, not just economically. As a human being, you have a huge problem! Because you have built something that you do not want to drive into the ground or want to give up, then everything would be for nothing! (Interviewee A01)

Our sample data shows that most self-funded entrepreneurs originally intended family succession as a stewardship exit strategy, this did not come to fruition. Many interviewees stated that they asked their children if they were willing to take over the company, but the children rejected the offer. Interviewee A06 talked about his children's rejection and his reaction:

Interviewee A06: I used to assert myself in the market. Unfortunately, not in the family! None of my children wanted to take over the company. Interviewer: Was that the reason for the sale? That you did not have a successor? [...] Interviewee A06: At some point, at fifty, fifty-five, you start thinking about who you are doing all that stuff for! And after all [your] children have turned it down—sell it!

In the case of Interviewee A06, family succession was not possible because the entrepreneur's children rejected his offer to take over the running of the company. In other cases of our sample data, family succession did not happen because the incumbents did not consider their children qualified to take over. A statement by A13, a 58-year-old interviewee, illustrates this situation. She considered her children either too young to lead a company or as lacking the requisite education for such a position. The entrepreneur stated the following:

Our children are in their early twenties. The twins are twenty-two, and our [elder] daughter has just turned twenty-four. The twins are studying business administration. That would have been an option in principle [two children with suitable education]. But honestly, you cannot let a beginner do this! That means that they would have to work somewhere else for at least two or three years. 
[...] Our [elder] daughter studies medicine. She is entirely out of the question [daughter lacks the requisite education]. (Interviewee A13)

When the interviewees saw that family succession was impossible, they considered other exit strategies. The self-funded entrepreneurs of our sample considered selling their companies to capable managers as part of a management buyout (MBO). This process is exemplified in the statement of Interviewee A11, a 60-year-old former owner of a landscaping company. He first expected that his son would take over his company. However, when this son rejected the offer, Interviewee A11 considered a management buyout. The following conversation illustrated the circumstances:

Interviewer: Can you explain the main reason why you sold the company? [...] Interviewee A11: I can! I can explain that very clearly. Interviewer: Yes? Interviewee A11: I mentioned before that I have two children. It became clear that my children have different orientations [from mine]. Interviewer: Really? Interviewee A11: My youngest son, who I considered suitable at twenty-three, decided differently. Dentistry! Then the question arises what to do when you turn sixty? [...] You think about how you can deal with it. Then some time passed. Then I thought about asking my employees. A young landscape architect, thirty, was suitable. The other one was an engineer, thirty-three years old. They have been working for the company for several years. The landscape architect had already done essential tasks that I used to do; accounting, marketing, and those things.

Many interviewees stated that a management buyout is only suitable for smaller companies since acquiring larger companies requires substantial financial resources that often cannot be raised by individual managers. This fact makes a management buyout for larger firms rather difficult. Interviewee B05, a 54-year-old certified public accountant, explains that it is rather difficult for an individual to buy a substantial company via MBO.

Corporations have the money, and they pay it! They put it on the table! There is cash! But an individual or a few managers?! That is difficult! (Interviewee B05)

When family succession and a management buyout are not practicable, selffunded firm owners have to opt for another exit strategy. This exit strategy is typically an acquisition as a harvest exit strategy. The following conversation with Interviewee B02, an M\&A consultant, summarizes the circumstances:

Interviewee B02: Usually, there is an attempt to conduct family succession for firms of this size [small entrepreneurial firms]. [...] In seventy percent of cases, it is possible to solve this either within the family or in the company, through a management buyout! When there is no one in the family, no son, daughter, or whatever. If no one exists, has no desire to do it, or is not capable. [...] That [MBO] will be considered. Can one of the foreman or a manager or someone do something like that? Maybe, with the support of the previous owner via loan or with the help of a bank or whatever, business start-up loan or something like 
that. Interviewer: Yes? Interviewee B02: But that does not always work! And then roughly the last thirty percent goes in the market. And that is why I say the main motive is age-related succession. Interviewer: So, the reason is because of age? Interviewee B02: Yes! Interviewer: Because these entrepreneurs are of a certain age? Let us say sixty, sixty-five, seventy years old? Interviewee B02: Yes. Interviewer: They cannot find a suitable successor in the family? For example, no daughter, no son, who can do it or who has the desire to do it? Interviewee B02: Exactly! Interviewer: And then they seek a successor from the company or an external investor? Interviewee B02: Yes, just like that! That is the headline, the main motive that dominates.

Many interviewees of the self-funded group stated that it was critical to leave their business in good hands even when the buyer is not the bidder with the highest offer. A conversation with Interviewee A12, a 60-year-old structural engineer, illustrates this:

Interviewee A12: I had already thought about that [firm exit]. I was not unprepared. I could afford to be picky because I was not pressed for time. We compared the offers based on our corporate policy from the perspective of the company's future. It was essential to me that when I leave, not only to see my financial advantages. Instead, to leave the whole team, the company, in good hands! Because it was more or less my life's work! I cared what happened to it. Interviewer: Yes? Interviewee A12: I was convinced, "okay, now I can leave." Let me put it this way; I do not have to feel guilty! The company is in good hands. I have done my best, and I have secured it for the long term.

Several interviewed consultants recognized that self-funded entrepreneurs often feel a sense of social responsibility to their employees. However, some consultants argued that this social behavior of such entrepreneurs is not motivated only by selflessness. The entrepreneurs' reputation in their local communities could also influence their business decisions, since many entrepreneurs are well known in their communities. Layoff of employees after the firm sale could negatively affect the entrepreneur's public image. Interviewee B02, an M\&A consultant, made this point:

That has mainly something to do with decency, that has something to do with responsibility. As I said, I have entrepreneurs here who said, "if you [will] introduce me to someone who wants to close my headquarters, then you [better] send him back home right away! That is out of the question for me at all!" That is one thing. The other thing is related to the fact that these companies are often in smaller communities. And they [the entrepreneurs] are in the golf club or in another club and are known locally! To the baker, to the butcher, and so on. [...] It often happens that entrepreneurs tell me: "If I sell my company and [the buyer] changes the headquarters or closes the location, then I cannot be seen in this place any longer. Then I am done here!" (Interviewee B02)

During the interview, many entrepreneurs of the self-funded group mentioned that they did not need to achieve a high revenue through the firm sale. They stated that they could financially take care of themselves in retirement even without the firm 
sale. The following conversation with the 60-year-old Interviewee A11 illustrates this:

Interviewer: It was not essential for you to achieve the highest possible sales price? Interviewee A11: No, No! I can answer that. It was not important! I am financially independent due to the properties that I have acquired over time. It was not critical to me that I achieve the highest possible sales price. It was rather important to me that I find a sales price that was fair. Fair for both sides.

Like Interviewee A11, most entrepreneurs of the self-funded group stated that they were not necessarily after achieving a high-revenue sale for their companies, since they are financially independent owing to their high income over the past decades. In contrast, the interviewees of the investor-backed group were not financially independent at the time of their firm exit. Fifty-year-old Interviewee A15 explained the difference between the two groups in detail:

Interviewee A15: I believe that financial independence is a crucial motive for people! Interviewer: Yes? Interviewee A15: That means a certain carelessness about the future, both for your family and your own life. A family-firm owner or the "classic" founder type [self-funded entrepreneur] usually achieves this with a good income. The founder achieves this [financial independence] through salary and dividend distributions, after five years or something like that. That means that he usually achieves financial independence while still with the company. The company provides security for him and his children and his family, and so on. It offers a stream of income that brings financial independence and thus freedom from material fears and worries. [...] That means the motive of financial independence is essential for a serial entrepreneur from the beginning. Because he [the investor-backed entrepreneur] usually accepts a very low salary. VCs [venture capitalists] want that! They want the pressure! That he [the investor-backed entrepreneur] says, "hey, we have to build something, with what we can quickly exit, with what I will finally get rich." That is the whole logic of investors! They make sure that a founder does not have too much money to live! Interviewer: Really? Interviewee A15: He [the investorbacked entrepreneur] will never feel that he is financially safe now! That is the mental game of investors!

This statement is consistent with the experience of the interviewed M\&A consultants. For example, consultant Interviewee B05 argued that self-funded entrepreneurs are, after several years of earning high income, not dependent on high revenues through the firm sale:

It [the company] is usually passed on in the family. Sometimes they make a deal like, "son, pay me a pension until the end of my life." So that he [the entrepreneur] can make a living from it. However, it usually is the case that entrepreneurs have already put money aside during [their] prosperous years. Have houses or stock portfolios. He [the entrepreneur] can then live a good life and no longer needs the company. That means he passes it [the company] on to his son or daughter and says, "here become happy with it, carry on." (Interviewee B05) 
Some interviewees considered the post-acquisition period of the firm as crucial. Since a transitional period is often necessary for implementing new management, some of the entrepreneurs were tied to the company for one to three years as part of an earn-out or consultancy contract. For several interviewees, this time was a welcome opportunity to have an influence on their life's work further. Interviewee A05, a 59-year-old former owner of a metal processing company, described the postacquisition period as follows:

Then, I was a consultant for the rest of the year until 31.12. [...] They paid me these six months. That was because you had to introduce the customers to the new owner. There were several meetings. (Interviewee A05)

Initial public offering is a harvest exit strategy. The interviewees of the self-funded group were asked about their attitudes towards IPOs. All interviewed entrepreneurs of this group had no desire to exit via an initial public offering. They did not give IPOs serious thoughts. A conversation with Interviewee A11 illustrates this:

Interviewer: Were there any other alternatives to the firm sale? For example, an IPO? [...] Interviewee A11: No, an IPO was unthinkable for our company! Interviewer: Yes? Interviewee A11: Simply in terms of size! Right? There is simply not enough mass! No!

The Interviewees of the self-funded group desired to exit via family succession, management buyout, and firm acquisition by a third party. They did not desire voluntary cessation exit strategies such as firm liquidation or business discontinuance.

\subsection{Investor-Backed Entrepreneurs' Exit Strategy Intentions}

Fig. 3 illustrates first-order concepts and second-order themes of our grounded theory framework. The framework explains why the interviewees of the investors-backed group opted for acquisition as an exit strategy.

In general, the financial interests of the investor-backed entrepreneurs are more dominant than those of the entrepreneurs of the self-funded group. The interviewees' emotional bonds with their companies and employees were weaker compared to the interviewees of the other group. A conversation with Interviewee A15 illustrates this:

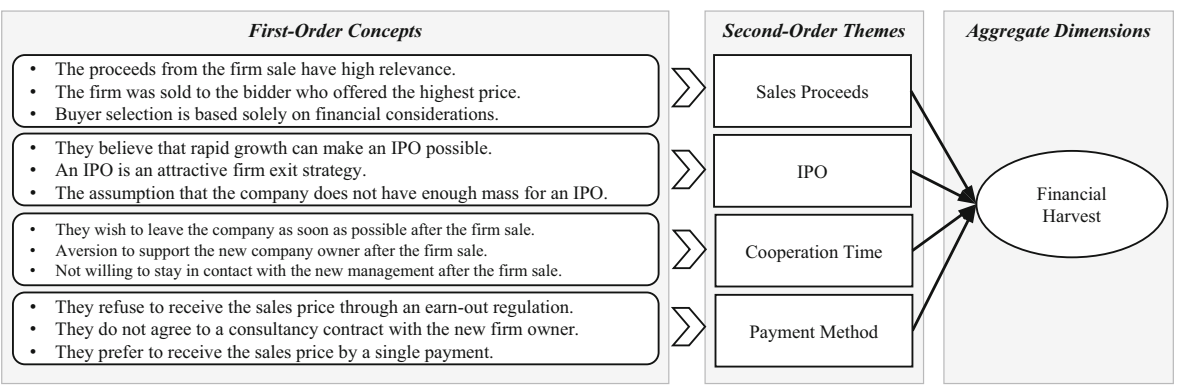

Fig. 3 Exit Strategy Intention of Investor-Backed Entrepreneurs 
Interviewee A15: It was a financial motive for me, in 2015, to sell my company shares to XXX [company name]. [...] Interviewer: You knew that the XXX group would probably treat your employees well? That they do not cut wages and do not plan many layoffs? Did you know that? Interviewee A15: I knew that, but I would have sold it anyway! If you want to know with your question, so to speak, if whether the financial aspect was more important to me or the future of the employees, then the financial aspect was more important to me.

Investor-backed entrepreneurs generally do not see their firms as their life's work that they have to pass on to their children. For the interviewees of this group, it was more important to sell their companies at the highest possible price, compared to the entrepreneurs of the self-funded group. Interviewee B08, a 49-year-old consultant, described this as follows:

We always differentiate between an entrepreneur and someone who simply implemented a business idea. There are significant differences, especially among the younger ones. Many of the younger founders in the IT sector or the internet sector think that they can achieve an exorbitant sales price because they have successfully built something within three or five years. In this context, I would say that they set humanness aside! We have had some who were very successful in software development in their mid-thirties and could sell for double-digit million amounts. They absolutely do not care what happens afterward [to their former companies after the firm sale]. (Interviewee B08)

For the interviewees of the investor-backed group, an exit through an initial public offering is a desirable harvest exit strategy. This strategy offers firm owners a high financial return. Many interviewees of this group considered initial public offerings the most attractive exit strategy. For example, A02, a 43-year-old interviewee, described an IPO as the silver bullet:

Interviewee A02: The silver bullet would be like Google or Facebook did. Where they [the founders] say we will make an initial public offering, and we make the initial public offering in such a way that we retain complete control! Interviewer: Yes? Interviewee A02: But, hardly anyone in Europe has achieved that! But even if a European goes public, which is extremely rare, he [the founder] usually does not manage to maintain complete control [of the company].

Usually, venture capitalists invest in investor-backed entrepreneurs' companies for a fixed period. When this period is over, the investors demand for their capital plus dividend according to their agreements with the entrepreneurs. Interviewee B02, an M\&A consultant, described the agreements between investors and entrepreneurs as follows:

Interviewee B02: Regardless of whether the investor is a venture capital or startup financing company, or whether it is a private investor, or whatever, they are absolutely not interested in the business! They have to understand the business, of course, otherwise, they will not give any money, that is clear. But despite that, 
they are not interested in the business! Instead, they say, for example, "I want my investment back in three or five years with the following annual rate of return." Yes? Interviewer: Yes. Interviewee B02: Only under these conditions, so to speak.

To make initial public offerings possible, entrepreneurial firms must grow immensely in a relatively short period. Interviewees of the investor-backed group stated that only very few entrepreneurs succeed in this task. For example, Interviewee A02 was of the opinion that most entrepreneurs opt for a firm sale.

That it [the company] grows so that you can make an initial public offering. But the most likely scenario with all these companies is always the sale! You can see that on a grand scale with XXX [company name]. Sure, there are one or two major IPOs, but the rest are always somehow sold to someone. (Interviewee A02)

The entrepreneurs of the investor-backed group had contracts with their investors. These contracts included a fixed investment period after which the investors reclaimed their money plus interest. Moreover, the entrepreneurs agreed to contract clauses that implied that when the investors wanted to sell their company shares to a third party, they must sell their shares too. The following conversation with the 29-year-old Interviewee A19 exemplifies these contract conditions:

Interviewee A19: The so-called "drag-along" and "tag-along" clauses are common in standard VC contracts. [...] In our case the clause was so designed that there was a sales revenue, and if someone put this sales revenue on the table-a certain amount has been reached - then a simple majority of the shareholders could say, "we want to sell," and everyone else must sell too. Interviewer: Okay. Interviewee A19: So, basically a minimum return. To say, "okay, if we are all satisfied," and for example, "we have all tripled, quadrupled our money," then nobody can say "no."

None of the interviewees of our sample was able to achieve an initial public offering during the investment period. Start-up companies need to grow enormously to meet the financial requirements to initiate an IPO. Moreover, an initial public offering involves strenuous legal requirements as well. Interviewee B01 is a lawyer who specializes in M\&A laws. As the following statement shows, the complex legal regulations in Germany are trying for most entrepreneurs:

For that [IPO], they [the founders] are, in fact, too small and would also be absolutely overwhelmed with the stock and capital market regulations! As an owner-managed company, they need to get a trial lawyer into the house in advance. Because they just could not cope with the ad hoc priorities. (Interviewee B01)

As explained, the legacy idea was weaker in the group of investor-backed entrepreneurs. The interviewees of this group wanted to exit their companies through a single payment and then found a new company as soon as possible. In contrast to the interviewees of the self-funded group, payment via earn-out is not favorable for 
interviewees of the investor-backed group. The following statement by Interviewee A02 illustrates this preference:

In a so-called "earn-out period," he [the entrepreneur] gets a part of the sales price, but only when specific goals have been achieved or when a particular period of time has passed. I know that from many of my colleagues and friends who have done something like this. They are always highly frustrated during this period! [...] And that is why I personally always try to avoid such a scenario where I work for someone else; otherwise, I am not an entrepreneur! (Interviewee A02)

\subsection{Varying Exit Strategy Intentions Within the Two Groups}

The data from our sample suggests that most of the self-funded entrepreneurs intended family succession as a stewardship exit strategy, but this intention could not be fulfilled. These exit preferences have been observed by M\&A consultants, such as Interviewee B03:

You can see that, of course, not the majority of companies are sold. But the majority of companies are actually still handed down and transferred to the next generation. Seen in this way, the sale of a company is a unique situation, at least in Germany. [...] So it is not usually the priority of the founder and owner to sell! The priority is to keep the company as long as possible or transfer it to the next generation or, if it is possible, for his wife to inherit it, etc. (Interviewee B03)

Because of the previously shown empirical indications of an initially intended stewardship exit strategy, we propose the following:

Proposition 1. Self-funded entrepreneurs tend to choose a stewardship exit strategy (i.e., family succession or management buyout) rather than a financial harvest exit strategy or a voluntary cessation exit strategy.

The legacy idea was much weaker in the group of investor-backed entrepreneurs. These interviewees wanted to leave their company soon, at best through a single payment, and start a new business with adequate financial resources. Compared to the self-funded firm owners, their financial interests were more dominant. An exit through an IPO or acquisition was a desirable harvest strategy for these interviewees. Therefore, we propose the following:

Proposition 2. Investor-backed entrepreneurs tend to choose a financial harvest exit strategy (i.e., acquisition or initial public offering) rather than a stewardship exit strategy or a voluntary cessation exit strategy. 


\section{Discussion}

In the following, the socioemotional wealth concept from Gómez-Mejía et al. (2007) will be utilized to understand the different exit intentions of the entrepreneurs of the investor-backed and self-funded groups.

\subsection{Differences Between the Two Groups in Terms of Their Wealth at Risk}

We assume that the intended exit strategy of the interviewed entrepreneurs depended on differences in their loss aversion in terms of socioemotional wealth and financial wealth. We expect that the interviewees of the self-funded group had a higher emotional attachment to their firms and increased social ties to stakeholders than the interviewees of the other group. Because of this indication, we expect that the interviewees of the self-funded group held much more socioemotional wealth than the interviewees of the investor-backed group. This implies that the interviewees of the self-funded group had much higher socioemotional wealth at risk when making business-related decisions. The interviewees of the investor-backed group had a lower emotional attachment to their firms and less social ties to stakeholders than the other group. This can be explained by the shorter time they stayed in their companies compared to the entrepreneurs of the self-funded group. This fact made longlasting social ties to stakeholders less likely. Moreover, the involvement of investors suggests that the investor-backed interviewees owned lesser shares in their companies than the interviewees of the self-funded group in theirs. Fewer shares mean less control in business-related decisions. This suggests that these interviewees could not shape their companies as they wished, but the interviewees of the other group could. We expect that these facts led to a lower level of socioemotional wealth for the interviewees of the investor-backed group.

The socioemotional wealth model presented by Gómez-Mejía et al. (2007) was initially developed to explain decision differences between family and non-family firm principals. In general, the entrepreneurship literature distinguishes family firms from non-family firms according to the substantial influence of an owner family on business affairs. Gómez-Mejía et al. (2011, p. 692) state that family firms are distinctive from non-family firms because of attributes like "emotional attachment, sibling involvement, sense of legacy, family control, and concern for reputation." In the family firm literature, a wide range of definitions exist regarding the point at which family influence on a firm begins, turning the firm into a family firm (Anderson and Reeb 2003; Sciascia and Mazzola 2008; Sharma and Nordqvist 2008). Therefore, it is doubtful "that there will ever be a standard operational definition of a family firm” (Gómez-Mejía et al. 2011, p. 660).

While the self-funded entrepreneurs of our sample were emotionally attached to their companies, they could not be classified as family firm owners. Nearly all firms of this group were established by the interviewees and therefore owned in the first generation. Furthermore, most companies of the self-funded group were solely owned and managed by the interviewees themselves. The interviewees of this group built and shaped their companies after their own ideas over decades. Since their family members owned no shares in the companies, their influences on business 
decisions were relatively small. Therefore, we can classify the companies of the self-funded group as non-family firms that might become family firms. In other words, we consider these companies to be in a pre-family firm phase.

Nevertheless, this fact does not imply that the interviewees of the self-funded group had low levels of socioemotional wealth. It must be rather expected that these interviewees' socioemotional wealth level would be higher than that of successors in later generations. This phenomenon is known as generational drift (Corbetta and Salvato 2012) and suggests the progressive decay of family members' identification with the firm. Corbetta and Salvato (2012) state that the identification by individuals decreases in every new generation and with every new family member that joins the business. This phenomenon can be explained by the growing business professionalism and higher performance thresholds in every new generation. It leads to successors focusing on financial factors instead of on emotional attachment to the company and social ties to stakeholders (Corbetta and Salvato 2012; Salvato et al. 2010; Stewart and Hitt 2012). Therefore, it is reasonable to consider the socioemotional wealth level of the entrepreneurs of the self-funded group as high.

We argue that entrepreneurs of the self-funded group had greater socioemotional wealth at risk than the entrepreneurs of the other group. This led to the selffunded entrepreneurs intending a stewardship exit strategy and the investor-backed entrepreneurs a financial harvest exit strategy. However, one might argue that the different exit strategy intentions of the entrepreneurs are linked to altruism. In general, altruism is understood as the desire to help others even when this help would be costly for the individual (Andreoni 1989). Several empirical studies in the field of psychology suggest that the altruistic tendencies of individuals increase with age (e.g., Freund and Blanchard-Field 2014; Hubbard et al. 2016; Midlarsky and Hannah 1989). When comparing stewardship exit strategies and financial harvest exit strategies, it is reasonable to assume that stewardship exit strategies are motivated more by altruistic tendencies than financial harvest exit strategies. The interviewed entrepreneurs of the self-funded group are on average 17 years older than the interviewees of the investor-backed firm owner group. Therefore, it is reasonable to assume that the different exit strategy intentions of the entrepreneurs are linked to the age differences between the two groups, which resulted in more altruistic exit strategy intentions for one compared to the other.

However, this assumption is not consistent with our sample data. For example, Interviewee A15 was older at the time of his firm exit than Interviewee A01 and A08. This fact would imply that Interviewee A15 showed more altruistic tendencies than Interviewee A01 and A08, but this was not the case. Interviewee A15's statements show that his socioemotional wealth at risk had been significantly less than that of Interviewee A01 and A08. Therefore, we suppose that entrepreneurs' socioemotional wealth is instead related to the amount of time they spend in their companies before their exit. We assume that social ties to employees, managers, key customers, or key suppliers strengthen over time. We argue, therefore, that the time entrepreneurs stay in their companies before their exit is more likely a better indicator of the entrepreneurs' socioemotional wealth at risk than the entrepreneurs' age. This assumption is in line with our sample data, since the interviewees of the self- 
funded group stayed significantly longer in their ventures than the entrepreneurs of the other group ( 23 years compared to 4.6 years) before their exit from their firms.

\subsection{Analysis of the Underlying Processes Using the Theory of Planned Behavior}

Next, we employ the theory of planned behavior (Ajzen 1991, 2011; Ajzen and Fishbein 1980) to understand how individuals' exit intentions are linked to their actual exit paths. As mentioned before, according to the theory, an individual's intention is affected by three main factors, viz.: attitude, subjective social norms, and perceived behavioral control. In the following, we examine these three factors in the self-funded and investor-backed groups.

\subsubsection{Self-Funded Entrepreneurs' Exits from the Perspective of the Theory of Planned Behavior}

Our sample data suggests that the interviewees of the self-funded group originally intended family succession as a stewardship exit strategy. This type of exit strategy would offer the highest possible risk aversion in terms of socioemotional wealth. The interviewees would be able to hand over their life's work to their families' next generation. Since a descendant will be the new firm leader, it can be expected that the former firm owner will still have an influence on business decisions to some degree. The interviewees' statements show, on the other hand, that financial aspects played a minor role in their exit intentions. The self-funded interviewees reached financial independence through their high income over decades. Therefore, the perceived financial wealth at risk of the interviewees was relatively small.

From the perspective of the theory of planned behavior, the entrepreneurs' desire to retain control of their companies indicates the desirability of the family succession exit strategy. Family succession would ensure that a family member take over the business and let the interviewee still have control over the company to some degree. This exit strategy would therefore preserve the socioemotional wealth of the interviewees. The second important factor is the acceptability of the outcome of family succession by an important reference group. In this case, the interviewee's family members are the important reference group. The family members' statements about the advantages of being an entrepreneur indicate the acceptability of the outcome of family succession for the reference group. The third significant factor is the perceived behavioral control of the individual. This factor shows whether the interviewee considered the family succession exit strategy as feasible. The availability of a trusted and capable successor, who is willing to take over the company, indicates the feasibility of the succession. The entrepreneur will most likely engage in planned behavior that will lead to family succession if these three factors are fulfilled. This planned behavior could include activities such as introducing the successor to important customers, suppliers, employees, and partners, as well as preparing the successor for future duties and planning upcoming steps in the succession schedule.

We conclude that planned behavior that would have led to family succession did not occur in the self-funded group. The reason for this is that the entrepreneurs did not perceive the factor behavioral control as fulfilled. The feasibility of family suc- 
cession depends on the availability of a proper successor to take over the leadership of the company. The incumbent depends on the willingness of a family member to be the new leader of the company. Without a successor, family succession will certainly not take place. Nevertheless, the sole availability of a successor is not enough. The incumbent must consider the candidate as competent. This means that the successor needs to be educationally qualified to run the business. Moreover, the incumbent needs to perceive the successor as a trustworthy leader who will lead the company in line with the incumbent's vision. Otherwise, the incumbent would view family succession as unfeasible even when a potential successor is available. Accordingly, planned behavior that would result in family succession will not take place.

Because of the unfeasibility of family succession, the self-funded entrepreneurs opted for another exit strategy. A management buyout as stewardship exit strategy offered the second-highest level of risk aversion in terms of socioemotional wealth for the interviewees. Although the interviewees could not hand over their life's work to family successors, they could expect that long-lasing managers would similarly lead the company as they did. Moreover, the interviewees expected their social ties to key stakeholders to remain intact after their exit from the firms. An oft-described fear by the interviewees was that a new firm owner might subtract product lines, intellectual property, machinery, and equipment into a larger enterprise in another location. The interviewees expected that this would result in substantial job loss, which in turn would negatively affect the interviewees' public image in their local communities. These factors speak for the desirability and acceptability of the management buyout exit strategy. However, as for the family succession exit strategy, the entrepreneurs did not perceive the behavioral control factor as fulfilled. Management buyouts could not be executed when the interviewees' managers rejected the interviewees or the interviewees did not consider the managers suitable (e.g., the managers had insufficient financial resources for an MBO). Therefore, no planned behavior that would result in a management buyout took place. Because of the impracticability of a management buyout, the self-funded entrepreneurs opted for another exit path. The interviewees intended an acquisition as an exit strategy. However, a firm sale would lead to the interviewees losing all control over their companies. This implies that this exit strategy would lead to significant loss of the interviewee's socioemotional wealth. A firm sale was consequently the last intended exit strategy for the entrepreneurs of the self-funded group.

\subsubsection{Investor-Backed Entrepreneurs' Exits from the Perspective of the Theory of Planned Behavior}

As described earlier, the interviewees of the investor-backed group had a weaker emotional attachment to their firms and less social ties to stakeholders than the other group. Since the interviewees of the investor-backed group had fewer company shares than the interviewees of the other group, they were less likely to shape their companies after their own vision. In addition, the fact that they owned lesser company shares implies that their revenues were lower than those of the self-funded entrepreneurs. The interviewees' statements show that financial considerations played 
a major role in their exit strategy intentions. Compared to the other group, the entrepreneurs of the investor-backed group had no high income streams over decades. The financial wealth at risk was perceived as high by these interviewees. We expect that the socioemotional wealth level of the entrepreneurs of the investor-backed group was insignificant compared to that of the entrepreneurs of the self-funded group. This implies that the risk aversion of the investor-backed entrepreneurs was primarily linked to their financial wealth.

Next, we examine the exit intentions of the investor-backed group using the theory of planned behavior (Ajzen 1991, 2011; Ajzen and Fishbein 1980). The investor-backed entrepreneurs' statements that an initial public offering would be their preferred exit strategy indicate their desirability for this exit strategy. The interviewees assumed that, of all exit strategies, an initial public offering would yield the highest financial return. The next important factor is the acceptability of the initial public offering exit strategy by a critical reference group. Since investors owned the majority of the companies' shares, they had a strong influence on strategic decisions. Thus, the interviewees' investors are considered as an essential reference group. As explained before, investor-backed entrepreneurs have agreements with their investors. These agreements often state that the investment phase ends after a certain period of time. The interviewees often mentioned an investment period of three to five years. As soon as the investment period ends, the investors want financial returns for their commitments. This fact indicates the acceptability of the initial public offering exit strategy for this reference group, since this strategy would result in high financial returns for the investors. The interviewees of the investorbacked group stated that their companies needed to grow enormously before they could meet the IPO requirements of the stock market. Therefore, we conclude that the initial public offering exit strategy did not take place because the interviewees did not consider the behavioral control factor as fulfilled. In other words, firm exit via IPO was not feasible in the interviewees' eyes since their companies did not meet the demanding stock market requirements. The interviewees' initial exit intention did not lead to planned behavior that would result in an IPO. This planned behavior would have included upcoming steps that are necessary for an IPO, for instance, searching for a bank willing to support the company's IPO, changing the company's legal form to public, and publishing the company's corporate data.

Because of the unfeasibility of an IPO, the investor-backed entrepreneurs opted for another exit strategy. Acquisition as a financial harvest exit strategy offered the second-highest financial return for the interviewees. Thus, it was considered desirable by the interviewees. Moreover, firm sale was acceptable for the investors since it would coincide with the end of the investment period. Acquisition as an exit strategy is feasible at a lower growth phase since no difficult stock market requirements need to be fulfilled before the firm could be sold. Consequently, firm sale was the next intended exit strategy for the entrepreneurs of the investor-backed group. 


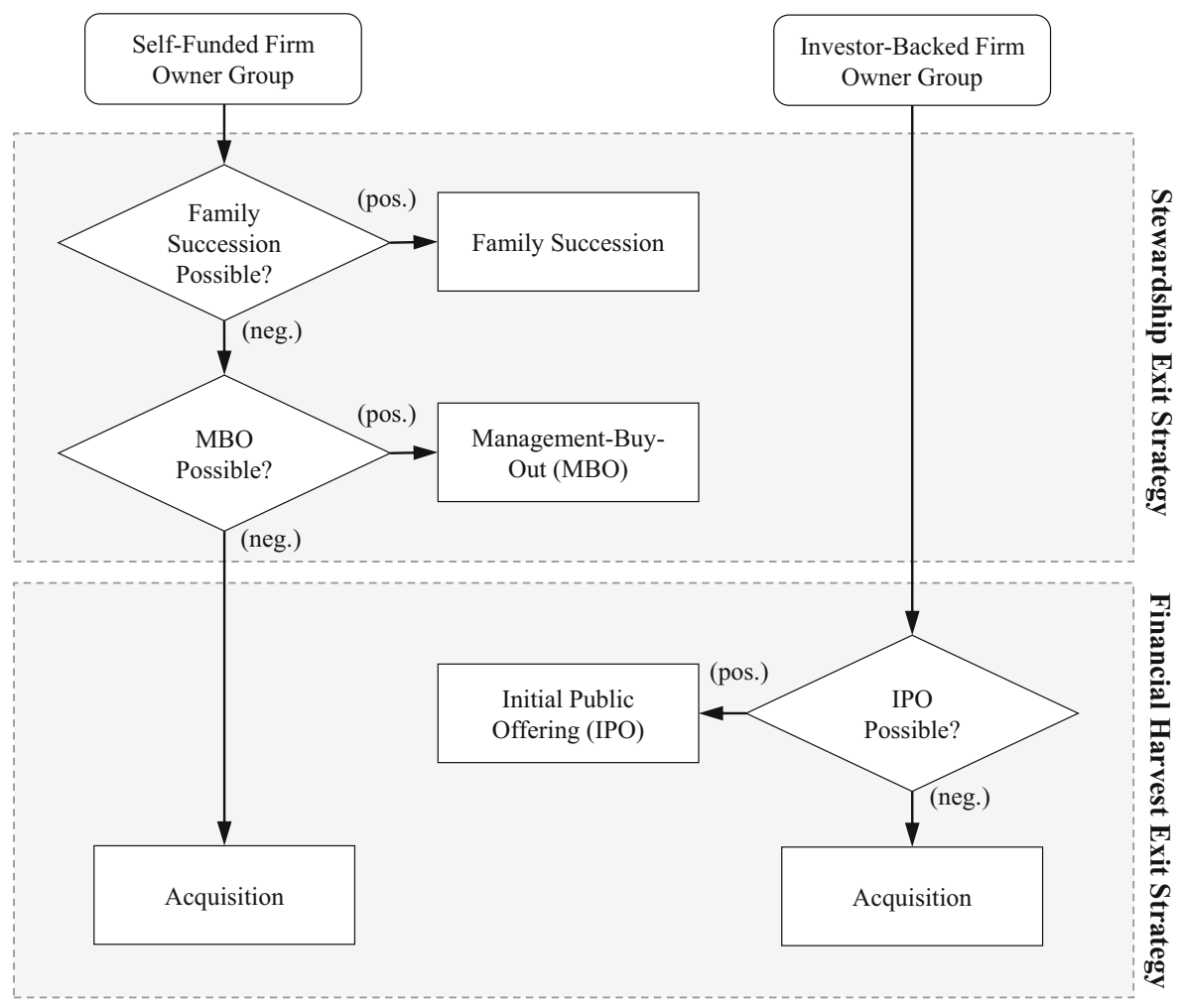

Fig. 4 Self-Funded and Investor-Backed Firm Owners' Exit Intentions

\subsection{Self-Funded and Investor-Backed Firm Owners' Exit Intentions}

We argue that entrepreneurs' exit strategy intentions depend on their perceived wealth at risk. This wealth can be divided into financial wealth and socioemotional wealth. We suppose that an entrepreneur's exit strategy intention results from a consideration of financial wealth and socioemotional wealth. Our assumption is in line with a recent study by Chirico et al. (2020), who are of the view that family firms weigh business exit options in terms of their impact on the family's financial wealth and socioemotional wealth.

For self-funded firm owners, their socioemotional wealth at risk in the event of a firm exit is more significant than their financial wealth at risk. Therefore, selffunded entrepreneurs tend to exit via a financial harvest exit strategy (i.e., acquisition) only after a stewardship exit strategy (i.e., family succession and management buyout) proves unfeasible (Proposition 1). For investor-backed firm owners, their financial wealth at risk seems greater than their socioemotional wealth at risk in the event of a firm exit. Therefore, investor-backed entrepreneurs tend to exit via a financial harvest exit strategy (i.e., initial public offering and acquisition) rather than a stewardship exit strategy or voluntary cessation exit strategy (Proposition 2). Fig. 4 illustrates this. 
The high level of emotional attachment of the self-founded firm owner group is in line with the results of a study by Kammerlander (2016), who concludes that nonfinancial considerations play an essential role for managing firm owners, especially in entrepreneurial ventures. The self-funded entrepreneurs of our study showed a strong attachment to their firms. Owners of family firms are associated with strong socioemotional attitudes in the entrepreneurship literature (e.g., Hernandez 2012; Zellweger and Astrachan 2008; Zellweger et al. 2012). The high level of emotional attachment of the self-funded entrepreneurs to their businesses can be explained by the generational drift phenomenon (Corbetta and Salvato 2012). Since the interviewees were first-generation owners and no other family members were involved in the business, their socioemotional wealth was expectedly high.

The investor-backed firm owners had already exited one or more businesses previously. Entrepreneurs of this group did not retire after their firm sale; instead, they go on to found new ventures. They are young, highly educated, own a few shares in their firms, and exploit technology-driven business ideas. These attributes are considered as the main characteristics of serial entrepreneurs in entrepreneurship literature (e.g., Westhead et al. 2005; Ucbasaran et al. 2008; Carbonara et al. 2020). Therefore, the interviewees of the investor-backed group can be referred to as investor-backed serial entrepreneurs. It must be said that the mentioned entrepreneurship studies do not examine serial entrepreneurs' emotional attachment to their businesses in regard to socioemotional wealth. This suggests that our paper gives novel insights by indicating the low socioemotional wealth levels of investorbacked serial entrepreneurs.

\section{Theoretical Contribution}

Chirico et al. (2020, p. 1344) state that research on "business exit is theoretically important in itself because it [business exit] is the most crucial strategic owners' action." The current paper contributes to the limited entrepreneurial exit literature. Our results show the different exit strategy intentions of self-funded and investorbacked entrepreneurs. Moreover, this paper provides deep insights into how these exit intentions lead to entrepreneurs' actual exit strategies. Explanations for different exit strategy intentions are presented by applying the theory of planned behavior (Ajzen 1991, 2011; Ajzen and Fishbein 1980) and the behavioral agency model (Wiseman and Gómez-Mejía 1998).

\section{Practical Implications}

This study has important practical implications for entrepreneurial M\&A activities. The behaviors of self-funded entrepreneurs during M\&A negotiations can leave acquirers confused; they may even consider these behaviors as idiosyncratic. Our study may help the buyer to understand the seller's exit concerns, which cannot be explained by financial considerations alone. Self-funded firm owners lose most, if not all, of their socioemotional wealth through the sale of their firms. This knowledge 
is vital for the buyer in the pre-acquisition phase to ease negotiations. Sellers can suddenly end negotiations with a potential buyer or stop supporting the acquirer after the firm sale, leaving the new management on their own. Taking the nonfinancial interests of the seller (i.e., legacy concerns and high emotional attachment) into account can help prevent misunderstandings and conflicts between both sides. This awareness can prevent high costs due to failed M\&A activities.

\section{Limitations and Future Directions}

It is important to know to what extent propositions made in this paper can be generalized. Due to the explorative nature of this study, restrictions have to be made on its generalizability. First, we used polar types (e.g., large and small companies, young and old entrepreneurs, different industries) to obtain high-contrast data patterns and quickly identify premature trends (Eisenhardt and Graebner 2007; Pettigrew 1990, 1992). The sample size is relatively small, which limits generalizability. Extensive quantitative studies are required to statistically verify our propositions. Second, some interviews were conducted post-acquisition, which may have led to rationalization bias in the data. Confidentiality is an essential factor in M\&A activities, especially in private SMEs. The buying and selling sides are highly interested in involving as few people as possible to avoid confusing employees, suppliers, and/or competitors. This fact makes it difficult to find entrepreneurs willing to involve third parties in the pre-acquisition phase. Third, female entrepreneurs are underrepresented in our sample data. The average rate of female entrepreneurs in German SMEs is about $16 \%$ (Schwartz 2021), and only 5\% of the entrepreneurs of our sample are female. While the authors assume that the presented results are gender-neutral, future studies should examine if there are gender-specific differences in the exit intentions of entrepreneurs. Fourth, our sample data has success bias. The companies survived many years before we interviewed their founders. Acquisitions are harvest exit strategies and, therefore, target companies must be successful to attract potential buyers (DeTienne et al. 2015). Unsuccessful companies would instead opt for voluntary cessation exit strategies such as liquidation or discontinuance. Nevertheless, we believe in the benefits of our study and that its contributions far outweigh these limitations.

We suggest that future research on entrepreneurial exit intentions focus on other exit strategies. It is of great interest if changes in exit strategy intentions are happening in other circumstances as well. For instance, do entrepreneurs change from an initially intended financial harvest exit strategy to a stewardship exit strategy, and, if yes, for what reasons?

\section{Conclusion}

Entrepreneurial exits are not only critical events in the life cycles of firms but are also inevitable events for all firm owners. Understanding these processes is beneficial for theory and practice. While knowledge on entrepreneurial exits has advanced, various aspects remain unexplored. Therefore, our research set out to provide novel insights 
into entrepreneurs' exit intentions. We hope our study meets this ambition, improves the depth of understanding of this phenomenon, and inspires additional research on entrepreneurial exit intentions.

Funding The study received no grant from any public, commercial, or non-profit funding agency.

Author Contribution Both authors contributed to the study's conception and design. Sascha Hohen prepared the materials and collected and analyzed data. Sascha Hohen wrote the first draft of the manuscript. Both authors commented on previous versions of the manuscript and approved the final manuscript.

Funding Open Access funding enabled and organized by Projekt DEAL.

Open Access This article is licensed under a Creative Commons Attribution 4.0 International License, which permits use, sharing, adaptation, distribution and reproduction in any medium or format, as long as you give appropriate credit to the original author(s) and the source, provide a link to the Creative Commons licence, and indicate if changes were made. The images or other third party material in this article are included in the article's Creative Commons licence, unless indicated otherwise in a credit line to the material. If material is not included in the article's Creative Commons licence and your intended use is not permitted by statutory regulation or exceeds the permitted use, you will need to obtain permission directly from the copyright holder. To view a copy of this licence, visit http://creativecommons.org/licenses/by/4. $0 \%$

Conflict of interest S. Hohen and L. Schweizer declarethat they have no competing interests.

\section{References}

Ahuja, Gautam, and Riitta Katila. 2001. Technological acquisitions and the innovation performance of acquiring firms: a longitudinal study. Strategic Management Journal https://doi.org/10.1002/smj.157.

Ajzen, Icek. 1991. The theory of planned behavior. Organizational Behavior and Human Decision Processes https://doi.org/10.1016/0749-5978(91)90020-T.

Ajzen, Icek. 2011. The theory of planned behavior: reactions and reflections. Psychology and Health https://doi.org/10.1080/08870446.2011.613995.

Ajzen, Icek, and Martin Fishbein. 1980. Understanding attitudes and predicting social behavior. Englewood Cliffs: Prentice-Hall.

Albert, Lumina S., and Dawn R. DeTienne. 2016. Founding resources and intentional exit sales strategies: an imprinting perspective. Group and Organization Management https://doi.org/10.1177/ 1059601116668762.

Aldrich, Howard E. 2015. Perpetually on the eve of destruction? Understanding exits in capitalist societies at multiple levels of analysis. In Research Handbook of Entrepreneurial Exit, ed. Dawn R. DeTienne, Karl Wennberg, 11-41. Cheltenham: Edward Elgar Publishing. https://doi.org/10.4337/ 9781782546979.00009 .

Anderson, Ronald C., and David M. Reeb. 2003. Founding-family ownership and firm performance: evidence from the S\&P 500. The Journal of Finance https://doi.org/10.1111/1540-6261.00567.

Andreoni, James. 1989. Giving with impure altruism: applications to charity and Ricardian equivalence. Journal of Political Economy https://doi.org/10.1086/261662.

Arnold, John, John Loan-Clarke, Crispin Coombs, Adrian Wilkinson, Jennifer Park, and Diane Preston. 2006. How well can the theory of planned behavior account for occupational intentions? Journal of Vocational Behavior https://doi.org/10.1016/j.jvb.2006.07.006.

Babich, Volodymyr, and Matthew J. Sobel. 2004. Pre-IPO operational and financial decisions. Journal of Management Science https://doi.org/10.1287/mnsc.1040.0252.

Bates, Timothy. 2005. Analysis of young, small firms that have closed: delineating successful from unsuccessful closures. Journal of Business Venturing https://doi.org/10.1016/j.jbusvent.2004.01.003.

Berrone, Pascual, Cristina Cruz, and Luis R. Gómez-Mejía. 2012. Socioemotional wealth in family firms: theoretical dimensions, assessment approaches, and agenda for future research. Family Business Review https://doi.org/10.1177/0894486511435355.

Brüderl, Josef, Peter Preisendörfer, and Rolf Ziegler. 1992. Survival chances of newly founded business organizations. American Sociological Review https://doi.org/10.2307/2096207. 
Capron, Laurence, Will Mitchell, and Anand Swaminathan. 2001. Asset divestiture following horizontal acquisitions: a dynamic view. Strategic Management Journal https://doi.org/10.1002/smj.175.

Carbonara, Emanuela, Hien Thu Tran, and Enrico Santarelli. 2020. Determinants of novice, portfolio, and serial entrepreneurship: an occupational choice approach. Small Business Economics https://doi.org/ 10.1007/s11187-019-00138-9.

Carr, Jon C., and Jennifer M. Sequeira. 2007. Prior family business exposure as intergenerational influence and entrepreneurial intent: a theory of planned behavior approach. Journal of Business Research https://doi.org/10.1016/j.jbusres.2006.12.016.

Carsrud, Alan, and Malin Brännback. 2011. Entrepreneurial motivations: what do we still need to know? Journal of Small Business Management https://doi.org/10.1111/j.1540-627X.2010.00312.x.

Cater, John J., and Robert T. Justis. 2009. The development of successors from followers to leaders in small family firms: an exploratory study. Family Business Review https://doi.org/10.1177/ 0894486508327822 .

Charmaz, Kathy. 2014. Constructing grounded theory. Thousand Oaks: SAGE.

Chirico, Francesco, Luis R. Gómez-Mejía, Karin Hellerstedt, Michael Withers, and Mattias Nordqvist. 2020. To merge, sell, or liquidate? Socioemotional wealth, family control, and the choice of business exit. Journal of Management https://doi.org/10.1177/0149206318818723.

Chrisman, James J., and Pankaj C. Patel. 2012. Variations in R\&D investments of family and non-family firms: behavioral agency and myopic loss aversion perspectives. Academy of Management Journal https://doi.org/10.5465/amj.2011.0211.

Chua, Jess H., James J. Chrisman, and Pramodita Sharma. 2003. Succession and non-succession concerns of family firms and agency relationship with non-family managers. Family Business Review https:// doi.org/10.1111/j.1741-6248.2003.00089.x.

Corbetta, Guido, and Carlo Salvato. 2012. Strategies for longevity in family firms. A European perspective. New York: Palgrave-Macmillan.

Corbin, Juliet M., and Anselm L. Strauss. 2015. Basics of qualitative research: techniques and procedures for developing grounded theory. Thousand Oaks: SAGE.

Cumming, Douglas. 2008. Contracts and exit in venture capital finance. Review of Financial Studies https:// doi.org/10.1093/rfs/hhn072.

Cyert, Richard M., and James G. March. 1992. Behavioral theory of the firm. Oxford: Wiley-Blackwell.

Daily, Catherine M., Trevis Certo, Dan R. Dalton, and Rungpen Roengpitya. 2003. IPO underpricing: a meta-analysis and research synthesis. Entrepreneurship Theory and Practice https://doi.org/10.1111/ 1540-8520.t01-1-00004.

Dalziel, Margaret. 2008. The seller's perspective on acquisition success: empirical evidence from the communications equipment industry. Journal of Engineering and Technology Management https://doi. org/10.1016/j.jengtecman.2008.06.005.

Denis, David J., Diane K. Denis, and Keven Yost. 2002. Global diversification, industrial diversification, and firm value. The Journal of Finance https://doi.org/10.1111/0022-1082.00485.

Denzin, Norman K. 1989. Interpretive biography. London: SAGE.

Denzin, Norman K. 2009. The research act: a theoretical introduction to sociological methods. Englewood Cliffs: Prentice Hall.

Denzin, Norman K., and Yvonna S. Lincoln. 2017. The SAGE handbook of qualitative research. Thousand Oaks: SAGE.

DeTienne, Dawn R. 2010. Entrepreneurial exit as a critical component of the entrepreneurial process: theoretical development. Journal of Business Venturing https://doi.org/10.1016/j.jbusvent.2008.05. 004.

DeTienne, Dawn R., and Melissa S. Cardon. 2012. Impact of founder experience on exit intentions. Small Business Economics https://doi.org/10.1007/s11187-010-9284-5.

DeTienne, Dawn R., and Karl Wennberg. 2016. Studying exit from entrepreneurship: new directions and insights. International Small Business Journal https://doi.org/10.1177/0266242615601202.

DeTienne, Dawn R., Alexander McKelvie, and Gaylen N. Chandler. 2015. Making sense of entrepreneurial exit strategies: a typology and test. Journal of Business Venturing https://doi.org/10.1016/j.jbusvent. 2014.07.007.

Eisenhardt, Kathleen M. 1989. Building theories from case study research. Academy of Management Review https://doi.org/10.5465/amr.1989.4308385.

Eisenhardt, Kathleen M., and Melissa E. Graebner. 2007. Theory building from cases: opportunities and challenges. Academy of Management Journal https://doi.org/10.5465/amj.2007.24160888. 
Esfandiar, Kourosh, Mohamad Sharifi-Tehrani, Stephen Pratt, and Levent Altinay. 2019. Understanding entrepreneurial intentions: a developed integrated structural model approach. Journal of Business Research https://doi.org/10.1016/j.jbusres.2017.10.045.

Ewens, Michael, and Matt Marx. 2018. Founder replacement and startup performance. The Review of Financial Studies https://doi.org/10.1093/rfs/hhx130.

Fayolle, Alain, and Francisco Liñán. 2014. The future of research on entrepreneurial intentions. Journal of Business Research https://doi.org/10.1016/j.jbusres.2013.11.024.

Feola, Rosangela, Massimiliano Vesci, Antonio Botti, and Roberto Parente. 2019. The determinants of entrepreneurial intention of young researchers: combining the theory of planned behavior with the triple helix model. Journal of Small Business Management https://doi.org/10.1111/jsbm.12361.

Fishbein, Martin, and Icek Ajzen. 1975. Belief, attitude, intention and behavior: an introduction to theory and research. Reading: Addison-Wesley.

Flick, Uwe. 2018. An introduction to qualitative research. Thousand Oaks: SAGE.

Freund, Alexandra M., and Fredda Blanchard-Fields. 2014. Age-related differences in altruism across adulthood: making personal financial gain versus contributing to the public good. Developmental Psychology https://doi.org/10.1037/a0034491.

Gimeno, Javier, Timothy B. Folta, Arnold C. Cooper, and Carolyn Y. Woo. 1997. Survival of the fittest? Entrepreneurial human capital and the persistence of underperforming firms. Administrative Science Quarterly https://doi.org/10.2307/2393656.

Glaser, Barney G., and Anselm L. Strauss. 1967. The discovery of grounded theory: strategies for qualitative research. Chicago: Aldine Publishing.

Goddard, Wayne, and Stuart Melville. 2004. Research methodology: an introduction. Oxford: Blackwell Publishing.

González-López, María J., María Carmen Pérez-López, and Lázaro Rodríguez-Ariza. 2019. Clearing the hurdles in the entrepreneurial race: the role of resilience in entrepreneurship education. Academy of Management Learning and Education https://doi.org/10.5465/amle.2016.0377.

Graebner, Melissa E., and Kathleen M. Eisenhardt. 2004. The seller's side of the story: acquisition as courtship and governance as syndicate in entrepreneurial firms. Administrative Science Quarterly https://doi.org/10.2307/4131440.

Graebner, Melissa E., Kathleen M. Eisenhardt, and Philip T. Roundy. 2010. Success and failure in technology acquisitions: lessons for buyers and sellers. Academy of Management Perspectives https://doi. org/10.5465/amp.24.3.73.

Graebner, Melissa E., Koen H. Heimeriks, Quy Huy Nguyen, and Eero Vaara. 2017. The process of postmerger integration: a review and agenda for future research. Academy of Management Annals https:// doi.org/10.5465/annals.2014.0078.

Gómez-Mejía, Luis R., Cristina Cruz, Pascual Berrone, and Julio De Castro. 2011. The bind that ties: socioemotional wealth preservation in family firms. Academy of Management Annals https://doi.org/ 10.5465/19416520.2011.593320.

Gómez-Mejía, Luis R., Ionela Neacsu, and Geoffrey Martin. 2019. CEO risk-taking and socioemotional wealth: The behavioral agency model, family control, and CEO option wealth. Journal of Management https://doi.org/10.1177/0149206317723711.

Gómez-Mejía, Luis R., Katalin Takács Haynes, Manuel Núñez-Nickel, Kathyrn J. Jacobson, and José Moyano-Fuentes. 2007. Socioemotional wealth and business risks in family-controlled firms: evidence from Spanish olive oil mills. Administrative Science Quarterly https://doi.org/10.2189/asqu. 52.1.106.

Haleblian, Jerayr, Cynthia E. Devers, Gerry McNamara, Mason A. Carpenter, and Robert B. Davison. 2009. Taking stock of what we know about mergers and acquisitions: a review and research agenda. Journal of Management https://doi.org/10.1177/0149206308330554.

Harhoff, Dietmar, Konrad Stahl, and Michaerl Woywode. 1998. Legal form, growth and exit of West German firms: empirical results from manufacturing, construction, trade and service industries. Journal of Industrial Economics https://doi.org/10.1111/1467-6451.00083.

Headd, Brian. 2003. Redefining business success: distinguishing between closure and failure. Small Business Economics https://doi.org/10.1023/A:1024433630958.

Hernandez, Morela. 2012. Toward an understanding of the psychology of stewardship. Academy of Management Review https://doi.org/10.5465/amr.2010.0363.

Hessels, Jolanda, Cornelius A. Rietveld, A. Roy Thurik, and Peter Van der Zwan. 2018. Depression and entrepreneurial exit. Perspective: Academy of Management. https://doi.org/10.5465/amp.2016.0183.

Hoskisson, Robert E., Francesco Chirico, Jinyong Zyung, and Eni Gambeta. 2017. Managerial risk taking. Journal of Management https://doi.org/10.1177/0149206316671583. 
Hsu, Dan K., Johan Wiklund, Stella E. Anderson, and Betty S. Coffey. 2016. Entrepreneurial exit intentions and the business-family interface. Journal of Business Venturing https://doi.org/10.1016/j.jbusvent. 2016.08.001.

Hubbard, Jason, William T. Harbaugh, Sanjay Srivastava, David Degras, and Ulrich Mayr. 2016. A general benevolence dimension that links neural, psychological, economic, and life-span data on altruistic tendencies. Journal of Experimental Psychology: General https://doi.org/10.1037/xge0000209.

Jenkins, Anna, John Steen, and Martie-Louise Verreynne. 2016. Entrepreneurial exit: who, what or to where? Regional relocation as a form of exit. In Research handbook of entrepreneurial exit, ed. Dawn R. DeTienne, Karl Wennberg, 246-261. Cheltenham: Edward Elgar Publishing. https://doi.org/10. 4337/9781782546979.00020.

Jensen, Michael C., and William H. Meckling. 1976. The theory of the firm: managerial behavior, agency cost, and ownership structure. Journal of Financial Economics https://doi.org/10.1016/0304405X(76)90026-X.

Jick, Todd D. 1979. Mixing qualitative and quantitative methods: triangulation in action. Administrative Science Quarterly https://doi.org/10.2307/2392366.

Justo, Rachida, Dawn R. DeTienne, and Philipp Sieger. 2015. Failure or voluntary exit? Reassessing the female underperformance hypothesis. Journal of Business Venturing https://doi.org/10.1016/j.jbusvent. 2015.04.004.

Kahneman, Daniel, and Amos Tversky. 1979. Prospect theory: an analysis of decision under risk. Econometrica https://doi.org/10.2307/1914185.

Kammerlander, Nadine. 2016. I want this firm to be in good hands: emotional pricing of resigning entrepreneurs. International Small Business Journal https://doi.org/10.1177/0266242614541287.

Kautonen, Teemu, Marco van Gelderen, and Matthias Fink. 2015. Robustness of the theory of planned behavior in predicting entrepreneurial intentions and actions. Entrepreneurship Theory and Practice https://doi.org/10.1111/etap.12056.

Kotlar, Josip, Andrea Signori, Alfredo De Massis, and Silvio Vismara. 2018. Financial wealth, socioemotional wealth and IPO underpricing in family firms: a two-stage gamble model. Academy of Management Journal https://doi.org/10.5465/amj.2016.0256.

Krueger, Norris F. 2009. Entrepreneurial intentions are dead: long live entrepreneurial intentions. In Understanding the entrepreneurial mind: opening the black box, ed. Malin Brännback, Alan L. Carsrud, 51-72. New York: Springer.

Krueger, Norris F., and Alan L. Carsrud. 1993. Entrepreneurial intentions: applying the theory of planned behavior. Entrepreneurship and Regional Development https://doi.org/10.1080/08985629300000020.

Kuckartz, Udo. 2018. Qualitative Inhaltsanalyse. Methoden, Praxis, Computerunterstützung. Weinheim: Beltz.

Laitinen, Erkki K. 1992. Prediction of failure of a newly founded firm. Journal of Business Venturing https://doi.org/10.1016/0883-9026(92)90005-C.

Lee, Lena, Kam Wong Poh, Maw Der Foo, and Aegean Leung. 2011. Entrepreneurial intentions: the influence of organizational and individual factors. Journal of Business Venturing https://doi.org/10.1016/ j.jbusvent.2009.04.003.

Leitterstorf, Max P., and Sabine B. Rau. 2014. Socioemotional wealth and IPO underpricing of family firms. Strategic Management Journal https://doi.org/10.1002/smj.2236.

Leonard-Barton, Dorothy. 1990. A dual methodology for case studies: synergistic use of a longitudinal single site with replicated multiple sites. Organization Science https://doi.org/10.1287/orsc.1.3.248.

Liñán, Francisco, and Yi -Wen Chen. 2009. Development and cross-cultural application of a specific instrument to measure entrepreneurial intentions. Entrepreneurship Theory and Practice https://doi.org/10. 1111/j.1540-6520.2009.00318.x.

March, James G., and Zur Shapira. 1992. Variable risk preferences and the focus of attention. Psychological Review https://doi.org/10.1037/0033-295X.99.1.172.

McGuire, Jean B. 1988. Agency Theory and Organizational Analysis. Managerial Finance. https://doi.org/ 10.1108/eb013601.

McLarty, Benjamin D., and Daniel T. Holt. 2019. A bright side to family firms: how socioemotional wealth importance affects dark traits-job performance relationships. Family Business Review https://doi.org/ $10.1177 / 0894486519888397$.

Midlarsky, Elizabeth, and Mary E. Hannah. 1989. The generous elderly: naturalistic studies of donations across the life span. Psychology and Aging https://doi.org/10.1037/0882-7974.4.3.346.

Miles, Matthew B., Michael Huberman, and Johnny Saldana. 2019. Qualitative data analysis: a methods sourcebook. Thousand Oaks: SAGE. 
Morris, Michael H., Sohrab Soleimanof, and Rebecca J. White. 2020. Retirement of entrepreneurs: implications for entrepreneurial exit. Journal of Small Business Management https://doi.org/10.1111/jsbm. 12476.

Ozkan, Sevgi, and Irfan E. Kanat. 2011. E-government adoption model based on theory of planned behavior: empirical validation. Government Information Quarterly https://doi.org/10.1016/j.giq.2010. 10.007 .

Parker, Simon C., David J. Storey, and Arjen van Witteloostuijn. 2010. What happens to gazelles? The importance of dynamic management strategy. Small Business Economics https://doi.org/10.1007/ s11187-009-9250-2.

Patton, Michael Q. 2015. Qualitative research and evaluation methods: integrating theory and practice. Los Angeles: SAGE.

Pennings, Johannes M., Lee Kyungmook, and Arjen Van Witteloostuijn. 1998. Human capital, social capital and firm dissolution. Academy of Management Journal https://doi.org/10.5465/257082.

Pernecky, Tomas. 2016. Epistemology and metaphysics for qualitative research. Los Angeles: SAGE.

Pettigrew, Andrew M. 1990. Longitudinal field research on change: theory and practice. Organization Science https://doi.org/10.1287/orsc.1.3.267.

Pettigrew, Andrew M. 1992. The character and significance of strategy process research. Strategic Management Journal https://doi.org/10.1002/smj.4250130903.

Poulsen, Annette B., and Mike Stegemoller. 2008. Moving from private to public ownership: selling out to public firms versus initial public offerings. Financial Management https://doi.org/10.1111/j.1755053X.2008.00005.x.

Ranft, Annette L., and Michael D. Lord. 2002. Acquiring new technologies and capabilities: a grounded model of acquisition implementation. Organization Science. https://doi.org/10.1287/orsc.13.4.420. 2952.

Rees, Ray. 1985. The theory of principal and agent part I. Bulletin of Economic Research https://doi.org/ 10.1111/j.1467-8586.1985.tb00179.x.

Salvato, Carlo, Francesco Chirico, and Pramodita Sharma. 2010. A farewell to the business: championing exit and continuity in entrepreneurial family firms. Entrepreneurship and Regional Development https://doi.org/10.1080/08985621003726192.

Sardeshmukh, Shruti R., Michael Goldsby, and Ronda M. Smith. 2021. Are work stressors and emotional exhaustion driving exit intentions among business owners? Journal of Small Business Management https://doi.org/10.1111/jsbm.12477.

Schary, Martha A. 1991. The probability of exit. Rand Journal of Economics https://doi.org/10.2307/ 2601051.

Schulze, William S., and Franz W. Kellermanns. 2015. Reifying socioemotional wealth. Entrepreneurship Theory and Practice https://doi.org/10.1111/etap.12159.

Schwartz, Michael. 2021. Chefinnen im Mittelstand: Anteil der Frauen in Führung steigt nur leicht. KfW Research. https://www.kfw.de/PDF/Download-Center/Konzernthemen/Research/PDF-DokumenteVolkswirtschaft-Kompakt/One-Pager-2020/VK-Nr.-189-Januar-2020-Chefinnen.pdf. Accessed 15 Aug 2021.

Sciascia, Salvatore, and Pietro Mazzola. 2008. Family involvement in ownership and management: exploring nonlinear effects on performance. Family Business Review https://doi.org/10.1177/ 08944865080210040105.

Seth, Anju, Kean P. Song, and Richardson Pettit. 2002. Value creation and destruction in cross-border acquisitions: an empirical analysis of foreign acquisitions of US firms. Strategic Management Journal https://doi.org/10.1002/smj.264.

Sharma, Pramodita, and Mattias Nordqvist. 2008. A classification scheme for family firms: from family values to effective governance to firm performance. In Family values and value creation. A family business publication, ed. Josep Tàpies, John L. Ward, 71-101. London: Palgrave Macmillan. https:// doi.org/10.1057/9780230594227_5.

Sharma, Pramodita, and Sanjay Sharma. 2011. Drivers of proactive environmental strategy in family firms. Business Ethics Quarterly https://doi.org/10.5840/beq201121218.

Shavell, Steven. 1979. On moral hazard and insurance. Quarterly Journal of Economics. https://doi.org/ $10.2307 / 1884469$.

Sheppard, Blair H., Jon Hartwick, and Paul R. Warshaw. 1988. The theory of reasoned action: a metaanalysis of past research with recommendations and future research. Journal of Consumer Research https://doi.org/10.1086/209170.

Soleimanof, Sohrab, Michael H. Morris, and Imran Syed. 2016. The role of retirement intention in entrepreneurial firm exit. In Research handbook of entrepreneurial exit, ed. Dawn R. DeTi- 
enne, Karl Wennberg, 157-183. Cheltenham: Edward Elgar Publishing. https://doi.org/10.4337/ 9781782546979.00015.

Souder, David, Akbar Zaheer, Harry Sapienza, and Rebecca Ranucci. 2017. How family influence, socioemotional wealth, and competitive conditions shape new technology adoption. Strategic Management Journal https://doi.org/10.1002/smj.2614.

Souitaris, Vangelis, Stefania Zerbinati, Bo Peng, and Dean Shepherd. 2020. Should I stay or should I go? Founder power and exit via initial public offering. Academy of Management Journal https://doi.org/ 10.5465/amj.2017.0420.

Stewart, Alex, and Michael A. Hitt. 2012. Why can't a family business be more like a non-family business? Modes of professionalization in family firms. Family Business Review https://doi.org/10.1177/ 0894486511421665.

Strauss, Anselm L., and Juliet M. Corbin. 1990. Basics of qualitative research. Newbury Park: SAGE.

Sánchez, José C. 2013. The impact of an entrepreneurship education program on entrepreneurial competencies and intention. Journal of Small Business Management https://doi.org/10.1111/jsbm.12025.

Ucbasaran, Deniz, Gry A. Alsos, Paul Westhead, and Mike Wright. 2008. Habitual entrepreneurs. Foundations and Trends in Entrepreneurship https://doi.org/10.1561/0300000014.

Van Teeffelen, Lex, and Lorraine M. Uhlaner. 2013. Firm resource characteristics and human capital as predictors of exit choice: an exploratory study of SMEs. Entrepreneurship Research Journal https:// doi.org/10.1515/erj-2012-0008.

Welch, Xena, Stevo Pavićević, Thomas Keil, and Tomi Laamanen. 2020. The pre-deal phase of mergers and acquisitions: a review and research agenda. Journal of Management https://doi.org/10.1177/ 0149206319886908.

Wennberg, Karl. 2021. Exit. In World encyclopedia of entrepreneurship, ed. Léo-Paul Dana, 274-281. Cheltenham: Edward Elgar Publishing. https://doi.org/10.4337/9781839104145.00039.

Wennberg, Karl, and Dawn R. DeTienne. 2014. What do we really mean when we talk about 'exit'? A critical review of research on entrepreneurial exit. International Small Business Journal https://doi. org/10.1177/0266242613517126.

Wennberg, Karl, Johan Wiklund, Dawn R. DeTienne, and Melissa S. Cardon. 2010. Reconceptualizing entrepreneurial exit: divergent routes and their drivers. Journal of Business Venturing https://doi.org/ 10.1016/j.jbusvent.2009.01.001.

Westhead, Paul, Deniz Ucbasaran, Mike Wright, and Martin Binks. 2005. Novice, serial and portfolio entrepreneur behavior and contributions. Small Business Economics https://doi.org/10.1007/s11187003-6461-9.

Wiseman, Robert M., and Luis R. Gómez-Mejía. 1998. A behavioral agency model of managerial risk taking. Academy of Management Review https://doi.org/10.5465/amr.1998.192967.

Yin, Robert K. 2018. Case study research and applications: design and methods. Thousand Oaks: SAGE.

Zellweger, Thomas M., and Joseph H. Astrachan. 2008. On the emotional value of owning a firm. Family Business Review https://doi.org/10.1177/08944865080210040106.

Zellweger, Thomas M., and Tobias Dehlen. 2012. Value is in the eye of the owner: affect infusion and socioemotional wealth among family firm owners. Family Business Review https://doi.org/10.1177/ 0894486511416648.

Zellweger, Thomas M., Franz W. Kellermanns, James J. Chrisman, and Jess H. Chua. 2012. Family control and family firm valuations by family CEOs: the importance of intentions for transgenerational control. Organization Science https://doi.org/10.1287/orsc.1110.0665.

Zeng, Yuping, Thomas J. Douglas, and Wu Changqi. 2013. The seller's perspective on determinants of acquisition likelihood: insights from China's beer industry. Journal of Management Studies https:// doi.org/10.1111/joms. 12020 . 